\title{
Recent progress of the $\mathrm{Ca}-\mathrm{Cu}$ technology for decarbonisation of power plants and carbon intensive industries
}

\section{Citation for published version (APA):}

Martínez, I., Fernández, J. R., Martini, M., Gallucci, F., van Sint Annaland, M., Romano, M. C., \& Abanades, J. C. (2019). Recent progress of the $\mathrm{Ca}-\mathrm{Cu}$ technology for decarbonisation of power plants and carbon intensive industries. International Journal of Greenhouse Gas Control, 85, 71-85.

https://doi.org/10.1016/j.ijggc.2019.03.026

\section{Document license:}

TAVERNE

DOI:

10.1016/j.ijggc.2019.03.026

Document status and date:

Published: 01/06/2019

\section{Document Version:}

Publisher's PDF, also known as Version of Record (includes final page, issue and volume numbers)

\section{Please check the document version of this publication:}

- A submitted manuscript is the version of the article upon submission and before peer-review. There can be important differences between the submitted version and the official published version of record. People interested in the research are advised to contact the author for the final version of the publication, or visit the $\mathrm{DOI}$ to the publisher's website.

- The final author version and the galley proof are versions of the publication after peer review.

- The final published version features the final layout of the paper including the volume, issue and page numbers.

Link to publication

\section{General rights}

Copyright and moral rights for the publications made accessible in the public portal are retained by the authors and/or other copyright owners and it is a condition of accessing publications that users recognise and abide by the legal requirements associated with these rights.

- Users may download and print one copy of any publication from the public portal for the purpose of private study or research.

- You may not further distribute the material or use it for any profit-making activity or commercial gain

- You may freely distribute the URL identifying the publication in the public portal.

If the publication is distributed under the terms of Article 25fa of the Dutch Copyright Act, indicated by the "Taverne" license above, please follow below link for the End User Agreement:

www.tue.nl/taverne

Take down policy

If you believe that this document breaches copyright please contact us at:

openaccess@tue.nl

providing details and we will investigate your claim. 


\title{
Recent progress of the Ca-Cu technology for decarbonisation of power plants and carbon intensive industries
}

\author{
Isabel Martínez ${ }^{\mathrm{a}, *}$, Jose R. Fernández ${ }^{\mathrm{b}}$, Michela Martini ${ }^{\mathrm{c}}$, Fausto Gallucci ${ }^{\mathrm{c}}$, \\ Martin van Sint Annaland ${ }^{\mathrm{c}}$, Matteo C. Romano ${ }^{\mathrm{d}}$, Juan C. Abanades ${ }^{\mathrm{b}}$ \\ a Instituto de Carboquímica, Spanish Research Council (CSIC), Miguel Luesma Castán 4, 50018, Zaragoza, Spain \\ ${ }^{\mathrm{b}}$ Instituto Nacional del Carbón, Spanish Research Council (CSIC), Franciso Pintado Fe 26, 33011, Oviedo, Spain \\ ${ }^{\mathrm{c}}$ Department of Chemical Engineering and Chemistry, Eindhoven University of Technology, Het Kranenveld 14, Eindhoven, the Netherlands \\ ${ }^{\mathrm{d}}$ Politecnico di Milano, Department of Energy, via Lambruschini 4, 20156, Milan, Italy
}

\section{A R T I C L E I N F O}

\section{Keywords:}

$\mathrm{CO}_{2}$ capture

Sorption enhanced reforming

Calcium looping

Chemical looping

\begin{abstract}
A B S T R A C T
Highly efficient pre-combustion systems are sustainable alternatives for producing hydrogen with reduced carbon footprint. The Ca-Cu looping process is a novel $\mathrm{CO}_{2}$ capture process that combines Sorption Enhanced Reforming (SER) for the production of (almost) pure $\mathrm{H}_{2}$ with a $\mathrm{Cu} / \mathrm{CuO}$ redox cycle to regenerate the $\mathrm{CO}_{2}$ sorbent with a low energy penalty and potential reduction in capture cost. Over the last few years, the Ca-Cu looping process has seen noticeable progresses in its development and has recently been demonstrated up to TRL4/5 within the Ascent EU project, under conditions that are relevant for a range of industrial applications. This work reviews the most recent achievements and open gaps of knowledge in the development of this emerging process, focusing on experimental validation performed in lab-scale fixed bed reactors and on technoeconomic assessment of the application in industrial plants for hydrogen, ammonia and steel production.
\end{abstract}

\section{Introduction}

Hydrogen has gained importance as an alternative to fossil fuels due to its flexibility, fuel density and low carbon footprint at the end user. However, around $96 \%$ of the hydrogen production worldwide still uses fossil fuels as feedstock (Voldsund et al., 2016). On the other hand, $\mathrm{CO}_{2}$ capture and storage (CCS) remains as the best option for achieving drastic carbon dioxide emission cuts in large stationary sources (Edenhofer et al., 2014). For this reason, the deployment of large-scale hydrogen production technologies including $\mathrm{CO}_{2}$ capture (pre-combustion), with the aim of reducing the $\mathrm{H}_{2}$ production cost and improving the efficiency, may be crucial for the mitigation of climate change (Boot-Handford et al., 2014; Jansen et al., 2015; Voldsund et al., 2016).

Steam methane reforming (SMR) with simultaneous separation of $\mathrm{CO}_{2}$ has gained importance as a method for producing almost pure hydrogen with reduced carbon content in a single step (Di Giuliano and Gallucci, 2018; Harrison, 2008). In this process, referred to as sorption enhanced reforming (SER), the reforming of methane is carried out in the presence of a $\mathrm{CO}_{2}$ sorbent that separates in situ the $\mathrm{CO}_{2}$ from the gas phase, thereby pushing the reaction equilibrium towards hydrogen production. CaO-based materials have been commonly recommended as $\mathrm{CO}_{2}$ sorbents for the SER process due to their good performance, wide availability and favourable kinetics (Di Giuliano and Gallucci, 2018; Erans et al., 2016; Kierzkowska et al., 2013). Based on the equilibrium of the three main reactions taking place in the SER process (Eqs. 1-3), $\mathrm{H}_{2}$ contents of up to $96 \mathrm{vol} \%$ and about 1 vol.\% of $\mathrm{CO}$ and $\mathrm{CO}_{2}$ (on a dry basis) can be reached at $650-700{ }^{\circ} \mathrm{C}$ in one single step (Balasubramanian et al., 1999; Johnsen et al., 2006; Lopez Ortiz and Harrison, 2001; Yi and Harrison, 2005). Moreover, the energy released by the water gas shift (WGS) and carbonation reactions compensates for the endothermic steam reforming enthalpy, resulting in an almost neutral system where the need for external energy supply is avoided (unlike the energy-intensive SMR).

$$
\begin{aligned}
& \mathrm{CH}_{4}+\mathrm{H}_{2} \mathrm{O} \leftrightarrow \mathrm{CO}+3 \mathrm{H}_{2} \Delta \mathrm{H}_{298 \mathrm{~K}}=206.2 \mathrm{~kJ} / \mathrm{mol} \\
& \mathrm{CO}+\mathrm{H}_{2} \mathrm{O} \leftrightarrow \mathrm{CO}_{2}+\mathrm{H}_{2} \Delta \mathrm{H}_{298 \mathrm{~K}}=-41.0 \mathrm{~kJ} / \mathrm{mol} \\
& \mathrm{CaO}+\mathrm{CO}_{2} \leftrightarrow \mathrm{CaCO}_{3} \Delta \mathrm{H}_{298 \mathrm{~K}}=-178.8 \mathrm{~kJ} / \mathrm{mol}
\end{aligned}
$$

The main issue that has hindered so far the deployment of the SER process is the need to reduce the energy penalty associated to the regeneration of the $\mathrm{CO}_{2}$ sorbent (i.e. by $\mathrm{CaCO}_{3}$ calcination to generate

\footnotetext{
* Corresponding author.

E-mail address: imartinez@icb.csic.es (I. Martínez).
} 
pure $\mathrm{CO}_{2}$ and $\mathrm{CaO}$ ). The most widely proposed method to supply the energy required for $\mathrm{CaCO}_{3}$ calcination in both pre-combustion SER processes and in post-combustion Ca-Looping processes is the combustion of a fuel using a pure $\mathrm{O}_{2}$ stream as oxidant (Martínez et al., 2013b; Ochoa-Fernandez et al., 2007; Romano et al., 2011; Shimizu et al., 1999), which facilitates the purification of the $\mathrm{CO}_{2}$-rich stream generated for being subsequently stored. However, the energy consuming air separation unit (ASU) needed in this configuration affects noticeably both the efficiency and the capital cost of the technology. For this reason, alternative methods have been explored in the literature. Generally, the methods studied propose fulfilling the calciner heat demand by means of a solids stream at a high temperature coming from a third reactor (Fernández and Abanades, 2016; Martínez et al., 2011), transferring the heat needed indirectly to the regeneration chamber from a high temperature combustor by means of heat pipes (Reitz et al., 2015) or through a metallic wall separating both reactors (Abanades et al., 2005; Hodgson et al., 2018). However, the challenges associated to the design of the heat exchange surfaces or the operation of multiple interconnected fluidized beds limit the application of these methods at a sufficient scale (Martínez et al., 2016).

The decomposition of the $\mathrm{CaCO}_{3}$ formed during the hydrogen production step by means of an additional redox loop of $\mathrm{Cu} / \mathrm{CuO}$ was proposed (Abanades and Murillo, 2009) in order to boost the efficiency and reduce the cost of such calcination process in SER systems. The Ca$\mathrm{Cu}$ looping concept proposes the coupling in the same bed of solids the $\mathrm{CaCO}_{3}$ calcination together with the reduction of $\mathrm{CuO}$ (highly exothermic) using a gaseous fuel containing $\mathrm{H}_{2}, \mathrm{CO}$ and $\mathrm{CH}_{4}$. The thermal power supplied by the reduction of $\mathrm{CuO}$ avoids the need of energy consuming equipment like the ASU in oxy-fired calcination systems or costly heat exchange devices in indirect fired calciners referred above. This process has undergone a noticeable progress in terms of materials development, reactor design, experimental validation and process modelling analysis. The objective of this work is to review the most recent achievements for this emerging process, with a particular focus on the experimental validation (up to TRL4-5) of the most developed reactor concepts that involve packed-bed reactors operating in different reaction stages. This work also reviews techno-economic studies of the application as pre-combustion $\mathrm{CO}_{2}$ capture systems in hydrogen, ammonia and iron \& steel industries using a wider variety of reactor options.

\section{The Ca-Cu looping concept}

A simple arrangement of the main reaction steps of the $\mathrm{Ca}-\mathrm{Cu}$ looping process is shown in Fig. 1. Three functional materials are required to operate the process, namely a Cu-based material, a CaO-based $\mathrm{CO}_{2}$ sorbent and a reforming catalyst, all packed and mixed in the same bed at certain proportions (see below). Many studies have been done in the development of $\mathrm{Cu}$-based materials and $\mathrm{CO}_{2}$ sorbents with the

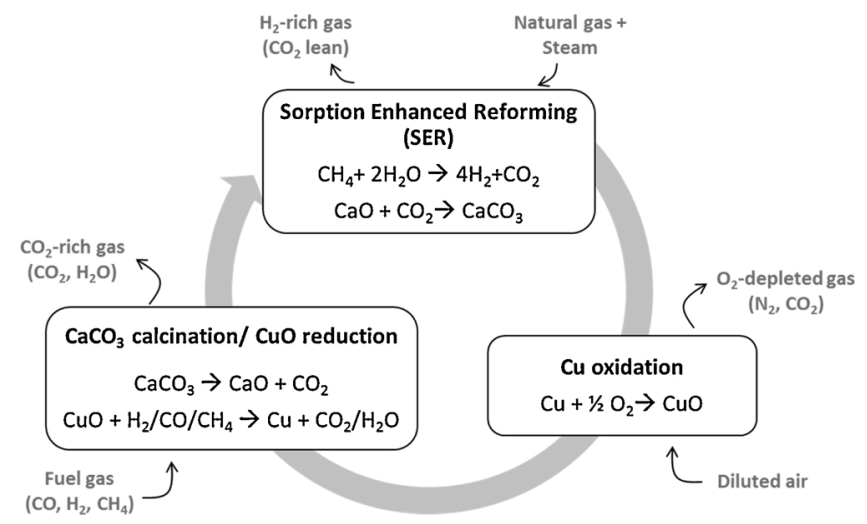

Fig. 1. Schematic of the $\mathrm{Ca}-\mathrm{Cu}$ looping process. requirements for this process, as recently reviewed by Fernández and Abanades (2017a, 2017b). A highly stable material with high proportion of $\mathrm{CuO}$ (i.e., over $60 \mathrm{wt} . \%$ ) is desired to reduce the amount of inert in the solid bed, which would absorb part of the energy released by $\mathrm{CuO}$ reduction (acting as a thermal ballast). Moreover, synthetic Ca-based materials with a highly steady $\mathrm{CO}_{2}$ carrying capacity along carbonation/calcination cycles are the preferred option for the $\mathrm{Ca}-\mathrm{Cu}$ process, leaving the naturally derived CaO-based sorbents, which decrease their maximum $\mathrm{CO}_{2}$ carrying capacity with the cycles, ruled out for this process (Fernández et al., 2012c). Finally, conventional reforming Nibased catalysts have been proposed for the SER stage. They have shown good performance under relevant conditions for the system (DíezMartín et al., 2018b; Grasa et al., 2017).

The $\mathrm{Ca}-\mathrm{Cu}$ process has been typically proposed to be operated in parallel pressurized fixed-bed reactors (Fernández et al., 2012c). This configuration allows the functional materials to remain steady whereas the reacting gases are repetitively switched between SER and redox conditions. $\mathrm{A} \mathrm{H}_{2}$-rich gas is first obtained through the SER of natural gas. Steam methane reforming (SMR), WGS and CaO carbonation take place simultaneously in the reactor, which is operated between 600 and $700{ }^{\circ} \mathrm{C}$ and between 10 and $25 \mathrm{bar}$, depending on the main output of the process (i.e., hydrogen or power production) (Fernández and Abanades, 2017c; Martínez et al., 2014, 2013a). The active CaO reacts with the $\mathrm{CO}_{2}$ to form $\mathrm{CaCO}_{3}$, whereas the reforming catalyst and the Cu-based solid continue unreacted. This operation finishes when the $\mathrm{CO}_{2}$ sorbent has been fully carbonated.

In the next reaction stage, diluted air is fed into the reactor to oxidise the $\mathrm{Cu}$-based solids under controlled pressure and temperature to limit the maximum bed temperature and avoid both the prompt $\mathrm{CaCO}_{3}$ calcination and operational issues related to the Cu-based material (i.e., agglomeration, secondary reactions and/or reactivity loss). Low temperature and $\mathrm{O}_{2}$ concentration in inlet air (i.e., around $300{ }^{\circ} \mathrm{C}$ and 3 vol. $\% \mathrm{O}_{2}$ ) allow the maximum temperature to be maintained under the safety margin of $830-850{ }^{\circ} \mathrm{C}$ that minimises the aforementioned issues (Alarcón et al., 2017; Díez-Martín et al., 2018b; Fernández et al., 2014, 2012c). This stage is also operated at high pressure to reduce the driving force towards $\mathrm{CaCO}_{3}$ decomposition. The dilution of inlet air is obtained by recirculating a large amount of the $\mathrm{O}_{2}$-depleted gas leaving this reactor.

The Ca-Cu loop is closed with the key step of the process that is the calcination of the $\mathrm{CaCO}_{3}$ by means of the exothermic reduction of $\mathrm{CuO}$ with $\mathrm{CH}_{4}, \mathrm{H}_{2}$ or $\mathrm{CO}$ (Fig. 1). This step is carried out at atmospheric pressure to reduce the calcination temperature to $850-870{ }^{\circ} \mathrm{C}$ (Baker, 1962). The proportion of $\mathrm{CaO}$ and $\mathrm{CuO}$ in the solid bed mainly depends on the fuel gas composition, since the energy released by $\mathrm{CuO}$ reduction should be enough for bringing the solids and gas up to $850-870^{\circ} \mathrm{C}$ and then driving the endothermic $\mathrm{CaCO}_{3}$ calcination. According to the enthalpies of the reactions (4-6), a maximum $\mathrm{CuO} / \mathrm{CaCO}_{3}$ molar ratio of 3.1 is required when using pure $\mathrm{CH}_{4}$ as fuel gas whereas only a $\mathrm{CuO}$ / $\mathrm{CaCO}_{3}$ molar ratio of 1.3 is needed if pure $\mathrm{CO}$ is used (Alarcón and Fernández, 2015). Typically, mixtures of $\mathrm{H}_{2}, \mathrm{CO}$ and $\mathrm{CH}_{4}$ are proposed for the reduction/calcination operation, which come from the off-gas of a hydrogen purification unit or from a separate reforming stage (Fernández and Abanades, 2017c; Martínez et al., 2014).

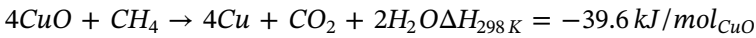

$\mathrm{CuO}+\mathrm{H}_{2} \rightarrow \mathrm{Cu}+\mathrm{H}_{2} \mathrm{O} \Delta \mathrm{H}_{298 \mathrm{~K}}=-86 \mathrm{~kJ} / \mathrm{mol}_{\mathrm{CuO}}$

$\mathrm{CuO}+\mathrm{CO} \rightarrow \mathrm{Cu}+\mathrm{CO}_{2} \Delta \mathrm{H}_{298 \mathrm{~K}}=-127 \mathrm{~kJ} / \mathrm{mol}_{\mathrm{CuO}}$ 


\section{Ca-Cu reactors design}

\subsection{Kinetics for the main reactions involved in the process}

Several dynamic reactor models have been elaborated to describe in detail each reaction step of the $\mathrm{Ca}-\mathrm{Cu}$ process. These are basically onedimensional models, in which well-known kinetic equations reported in the literature were implemented to represent the reaction rates.

For the SER stage, Fernández et al. (2012a) and Fernández and Abanades (2017b) developed a reactor model in which the kinetics reported by Xu and Froment (1989) were incorporated to represent both the steam methane reforming (SMR) and the WGS reactions using a Ni-based catalyst. In other study, Martini et al. (2016) used the kinetics from Numaguchi and Kikuchi (1988) for the SMR and WGS reactions in an attempt to avoid possible overestimation of the reaction rates when the stage is performed at high temperature and pressure with high content of $\mathrm{H}_{2} \mathrm{O}_{\text {(v) }}$ and no $\mathrm{H}_{2}$ in the inlet gas. Fernández et al. (2012a) and Fernández and Abanades (2017b) used the experimental equation proposed by Rodríguez et al. (2011) to estimate the carbonation of $\mathrm{CaO}$ during the SER operation, in which the reaction rate constant is assumed to be independent of the temperature when the carbonation takes place between 600 and $700{ }^{\circ} \mathrm{C}$. Martini et al. (2016) also used the shrinking core model (SCM) proposed by Lee (2004) to represent the carbonation of $\mathrm{CaO}$ during the SER. In a more recent work, Perreault and Patience (2016) reported a carbonation model at a particle scale for a combined $\mathrm{CuO} / \mathrm{CaO}$ material, which relies on the experimental results acquired in a packed bed. This model takes into account the progressive loss of reactivity observed in the solids after several cycles caused by increasing solid crystallinity.

The typical mechanism reported to represent the oxidation kinetics of Cu-based materials in chemical looping systems is the SCM. GarcíaLabiano et al. (2004) and Hamers et al. (2014) obtained the kinetic parameters using TGA for Cu-based solids containing around $10 \mathrm{wt} . \%$ of active phase. More recent works are focused on investigating the oxidation and reduction kinetics of $\mathrm{Cu}$-based materials with high $\mathrm{CuO}$ loadings (i.e., higher than $50 \mathrm{wt} . \% \mathrm{CuO}$ ), which makes them especially suitable for compact Ca-Cu looping systems. Díez-Martín et al. (2018a, 2018c) evaluated the oxidation kinetics of two Cu-based solids containing about $65 \mathrm{wt} . \% \mathrm{Cu}$ at atmospheric and pressurized conditions (up to 20 bar) in a thermogravimetric analyser (TGA). A SCM was used to describe the results obtained in the tests. It was also demonstrated that the operating pressure had no noticeable effect on oxidation kinetics. Then, the kinetic parameters calculated at atmospheric pressure described accurately the oxidation conversion at high pressure.

To model the $\mathrm{CuO}$ reduction/ $\mathrm{CaCO}_{3}$ calcination stage, the dynamic reactor models developed by Fernández and Abanades (2017b) and Martini et al. (2016) assumed the calcination kinetics obtained by Martínez et al. (2012), which considers an homogeneous reaction model to represent the calcination of two limestones with particle size below $300 \mu \mathrm{m}$ at temperatures of up to $920^{\circ} \mathrm{C}$ and $\mathrm{CO}_{2}$ partial pressures between 0 and $100 \mathrm{kPa}$. García-Lario et al. (2013) studied in a TGA the reduction kinetics of CuO-based material pellets containing $60 \mathrm{wt} . \%$ of $\mathrm{Cu}$, which showed reasonably fast reduction rates with $\mathrm{CH}_{4}, \mathrm{H}_{2}$ and $\mathrm{CO}$ at temperatures higher than $700{ }^{\circ} \mathrm{C}$, even after 100 reduction/oxidation cycles. The reduction rate was also modelled by means of a SCM. Qin et al. (2015) evaluated both reduction and calcination reaction rates using synthetic $\mathrm{CaCO}_{3}$ (99 wt.\% purity) and CuO-based (75 wt.\% CuO/ $\mathrm{Al}_{2} \mathrm{O}_{3}$ ) powders. TGA tests at temperatures up to $900{ }^{\circ} \mathrm{C}$ with inlet gases containing of up to $40 \mathrm{vol} . \%$ of $\mathrm{CH}_{4}$ (for the reduction) and $60 \mathrm{vol} . \%$ of $\mathrm{CO}_{2}$ (for the calcination) showed that a random nucleation model for the reduction reaction and an experimental equation for the $\mathrm{CaCO}_{3}$ calcination, based on that reported by Fang et al. (2009), described reasonably well the experimental data. In a more recent study, DíezMartín et al. (2018b) studied the reduction of a Cu-based solid in powder and pellet form $\left(65\right.$ wt. $\% \mathrm{Cu}$ ) with $\mathrm{H}_{2}, \mathrm{CO}$ and $\mathrm{CH}_{4}$ at $850{ }^{\circ} \mathrm{C}$ and evaluated its chemical stability throughout 100 redox cycles in a
TGA. The experimental data showed that a SCM controlled by the chemical reaction described well the reduction conversion of the solid. San Pio et al. (2018) investigated the reaction rates for both the oxygen uncoupling and reduction of CuO-based solids with active contents between 13 and $70 \mathrm{wt} . \%$. It was found that a grain model was suitable to fit both reactions using $\mathrm{H}_{2}$ as reducing agent at temperatures below $1000^{\circ} \mathrm{C}$. Regarding combined functional Ca-Cu materials, Qin et al. (2016a, 2016b) developed a changing grain size model to represent the decomposition of $\mathrm{CaCO}_{3}$ in homogeneously distributed $\mathrm{CaO}-\mathrm{CuO}$ solids. Moreover, the reduction of $\mathrm{CuO}$ was found to be faster when the solids presented large porosity and small grain size. In the case of core-in-shell $\mathrm{Ca}-\mathrm{Cu}$ composites (i.e., $\mathrm{CuO}$ grains located in the core and covered by a layer of $\mathrm{CaCO}_{3}$ ), the calcination reaction was described by means of an analogous particle model, in which the simultaneous $\mathrm{CuO}$ reduction/ $\mathrm{CaCO}_{3}$ calcination were only feasible at temperatures above $900{ }^{\circ} \mathrm{C}$ (Qin et al., 2016a).

\subsection{Reactor modelling}

As indicated above, an arrangement of packed-bed reactors performing at different pressure and temperature is the preferable process scheme to operate the Ca-Cu looping process. Diverse reactor models of different complexity are reported in the literature to describe each reaction step of the $\mathrm{Ca}-\mathrm{Cu}$ looping process.

Fernández et al. (2012b) defined a preliminary design of the $\mathrm{Ca}-\mathrm{Cu}$ process using a quite simple reactor model based on plug flow mode operation, in which steep reaction and heat exchange fronts were assumed, following an early approach by Noorman et al. (2007) and Eigenberger (2012) for packed bed chemical looping combustion reactors. This model approach served to define the operating conditions for every stage of the process (i.e., temperature, pressure, steam-tocarbon (S/C) ratio, etc). In later works, Fernández et al. (2012b, 2012a) developed a more elaborated pseudo-homogeneous model (PHM) to represent the SER stage of the process. The reactor model was designed for adiabatic conditions and assumed an ideal plug flow with negligible axial dispersion, taking into account the high velocities expected in large-scale reactors. Moreover, ideal gas behaviour, unvarying void fraction in the packed bed, uniform particle size and mixing for the functional solids, negligible catalyst deactivation and no dependence of physical properties with temperature and composition were also assumed for this model. These modelling works showed that during the SER operation, $\mathrm{H}_{2}$ concentrations of up to 95 vol.\% (on a dry basis) are feasible by operating at temperatures around $650{ }^{\circ} \mathrm{C}$, low pressures (below 20 bar), high S/C molar ratios (3-5) and catalyst/sorbent weight ratios of about 0.3 .

A similar model was also used by Fernández et al. (2013) to theoretically describe the oxidation step of the process. In this study, it was theoretically demonstrated that recirculating around $80-85 \%$ of the $\mathrm{N}_{2}$ rich stream produced during the oxidation to achieve about 3-4 vol.\% of $\mathrm{O}_{2}$ in the feed is enough for keeping the maximum temperature in the oxidation front below $850^{\circ} \mathrm{C}$, which limits the $\mathrm{CaCO}_{3}$ calcination when working under pressure.

Alarcón and Fernández (2015) developed a similar PHM to predict the performance of the $\mathrm{CO}_{2}$ sorbent regeneration step. In this case, axial mass and heat dispersion were assumed in the model. The effective bed conductivity $\lambda_{\text {eff }}$ was determined using the equation obtained by Vortmeyer and Berninger (2018). The convective heat transfer were described by the correlations reported by (Gunn, 1978) and Gunn and Misbah (1993). Axial mass dispersion was described using the equation proposed by Edwards and Richardson (1968). An analogous model was recently used by Fernández and Abanades (2017c) to simulate the continuous operation of a complete cycle of the $\mathrm{Ca}-\mathrm{Cu}$ looping process, considering that every reaction step started under the conditions of temperature and solids conversion left in the previous step.

To describe the $\mathrm{Ca}-\mathrm{Cu}$ process, Martini et al. (2016) developed a simplified reactor model assuming sharp fronts, which was based on the 
previous investigation carried out by Noorman et al. (2007) for chemical looping combustion (CLC) in fixed beds. This model considered the development of reaction fronts and heat exchange fronts that moves ahead in the bed at velocities calculated assuming complete conversion at the reaction front and very fast heat exchange between gas and solids. Moreover, the $\mathrm{Ca}-\mathrm{Cu}$ process was also simulated using a 1-D pseudo-homogeneous reactor model previously validated with experimental results for CLC (Hamers et al., 2014; Noorman et al., 2010) and chemical looping reforming (Spallina et al. (2017). This model considered both gas and solids components, accounted for axial mass and heat dispersion and ignored mass and heat transfer resistances between the gas and solid phases. Axial heat and mass transfer dispersion were estimated with the same equations used by Alarcón and Fernández (2015). The outcomes of both simple and advanced models were finally compared finding a good agreement between them concerning the temperature and concentration profiles.

In a more recent work, the same PHM model was used by Martini et al. (2017) to simulate the different stages of the $\mathrm{Ca}-\mathrm{Cu}$ process, in which the final condition of each step was assumed to be the starting point to initiate the following reaction step.

\section{Experimental validation at lab-scale of the $\mathrm{Ca}-\mathrm{Cu}$ process}

The feasibility of the reaction steps of the $\mathrm{Ca}-\mathrm{Cu}$ looping process was experimentally confirmed in packed-bed reactors up to TRL4-5 during the recently concluded EU-FP7 Project ASCENT ("ASCENT project, 2019"). Three different lab-scale facilities were used to validate individually each reaction stage of the process. The effect of the most important operating variables (i.e., $\mathrm{CH}_{4}$ spatial velocity needed for the SER stage, S/C ratio, $\mathrm{Cu} / \mathrm{Ca}$ molar ratio, etc) was assessed through specific experimentation for each individual stage accompanied by model validations. Once the operating conditions were defined, the feasibility of the full $\mathrm{Ca}-\mathrm{Cu}$ process was demonstrated through consecutive SER-oxidation-calcination/reduction cycles in two different lab-scale facilities using both commercial and synthetic materials specifically prepared during the ASCENT project.

\subsection{Lab-scale packed bed facilities description}

Three lab-scale packed bed facilities of different characteristics (located at ICB-CSIC, INCAR-CSIC and TU/e) have been used for the validation of the $\mathrm{Ca}-\mathrm{Cu}$ process. The fixed bed located at ICB-CSIC (Spain) is made of stainless steel with an internal diameter (ID) of $0.018 \mathrm{~m}$. It is externally heated by a 5 -m-long electric wire of $1.25 \mathrm{~kW}$. Solids bed height is around $0.2 \mathrm{~m}$ and it is located in the mid part of the reactor, as shown in Fig. 2. An external insulation of quartz wool surrounds the reactor and the electric wire to minimise the heat losses to the ambient. The axial temperature profile along the reactor length is measured through 15 thermocouples placed throughout the reactor. Bed temperature is controlled by a thermocouple located at the bottom of the fixed bed. The feed gas is introduced through the upper part after being preheated up to $400{ }^{\circ} \mathrm{C}$ in an electric oven, which also serves as evaporator when steam is needed. Water contained in a pressurised vessel is mixed with other inlet gases before being fed into the evaporator, as indicated in Fig. 2. Inlet gas flow rate and composition are regulated through the corresponding mass flow controllers. A condenser is placed downstream the reactor to separate the steam from the product gas. The operating pressure can be raised up to 10 bar by means of an end-valve. The concentration of permanent gases (e.g. $\mathrm{H}_{2}, \mathrm{CH}_{4}$, $\mathrm{CO}$ and $\mathrm{CO}_{2}$ ) is measured online using a SICK GMS810 analyser and a flow rate of $\mathrm{N}_{2}$ is used as internal standard for calculating the dry gas flow rate produced. In this facility, the feasibility of every reaction stage of the process, as well as their performance under cyclic tests, was demonstrated. Three functional materials were used for the experiments (with particle diameter between $0.6-2 \mathrm{~mm}$ ). A total mass of around $90 \mathrm{~g}$ was loaded in the reactor. Commercial $\mathrm{Cu}$ - and Ni-based catalysts $\left(72 \mathrm{wt} . \% \mathrm{CuO} / \mathrm{Al}_{2} \mathrm{O}_{3}\right.$ and $16-20 \mathrm{wt} . \% \mathrm{Ni} / \mathrm{CaAl}_{2} \mathrm{O}_{4}$ ), respectively) were used together with a synthetic $\mathrm{CaO}$-based sorbent synthetized by mechanical mixing using calcined limestone as $\mathrm{CaO}$ precursor and calcium aluminate cement as support. Specific information about the preparation route followed for this material as well as its textural properties and $\mathrm{CO}_{2}$ carrying capacity can be found elsewhere (Grasa et al., 2017). $\mathrm{CO}_{2}$ carrying capacity for this synthetic CaO-based sorbent resulted in $0.2 \mathrm{~g}_{\mathrm{CO} 2} / \mathrm{g}$ calcined sorbent in the long term.

The core of the experimental set-up built at INCAR-CSIC (Spain) consists of an Inconel tube ( $1 \mathrm{~m}$ long, ID of $0.038 \mathrm{~m}$ ), whose scheme is presented in Fig. 3. The axial temperature profile is registered in 15 points by a multipoint K-type thermocouple introduced from the upper part of the reactor. The tubular reactor is surrounded by an insulating layer $(0.15 \mathrm{~m}$ wide) of quartz wool that highly reduces the heat loss. A ceramic furnace of $14 \mathrm{~kW}$ surrounds the tubular reactor and the thermal insulation in order to preheat fixed bed and compensate the heat loss during the experiments. Moreover, two heating-tapes of $800 \mathrm{~W}$ preheat the inlet gas, as depicted in Fig. 3. The flow rate and inlet gas composition are regulated by Bronkhorst mass-flow controllers. A bed with silica gel situated downstream of the reactor exit is used to eliminate the steam contained in the product gas. Finally, a SICK GMS810 analyser equipped with infrared (for $\mathrm{CO}, \mathrm{CH}_{4}$ and $\mathrm{CO}_{2}$ ), paramagnetic (for $\mathrm{O}_{2}$ ) and thermal conductivity (for $\mathrm{H}_{2}$ ) detectors measures the composition of the product gas. The experiments were carried out at

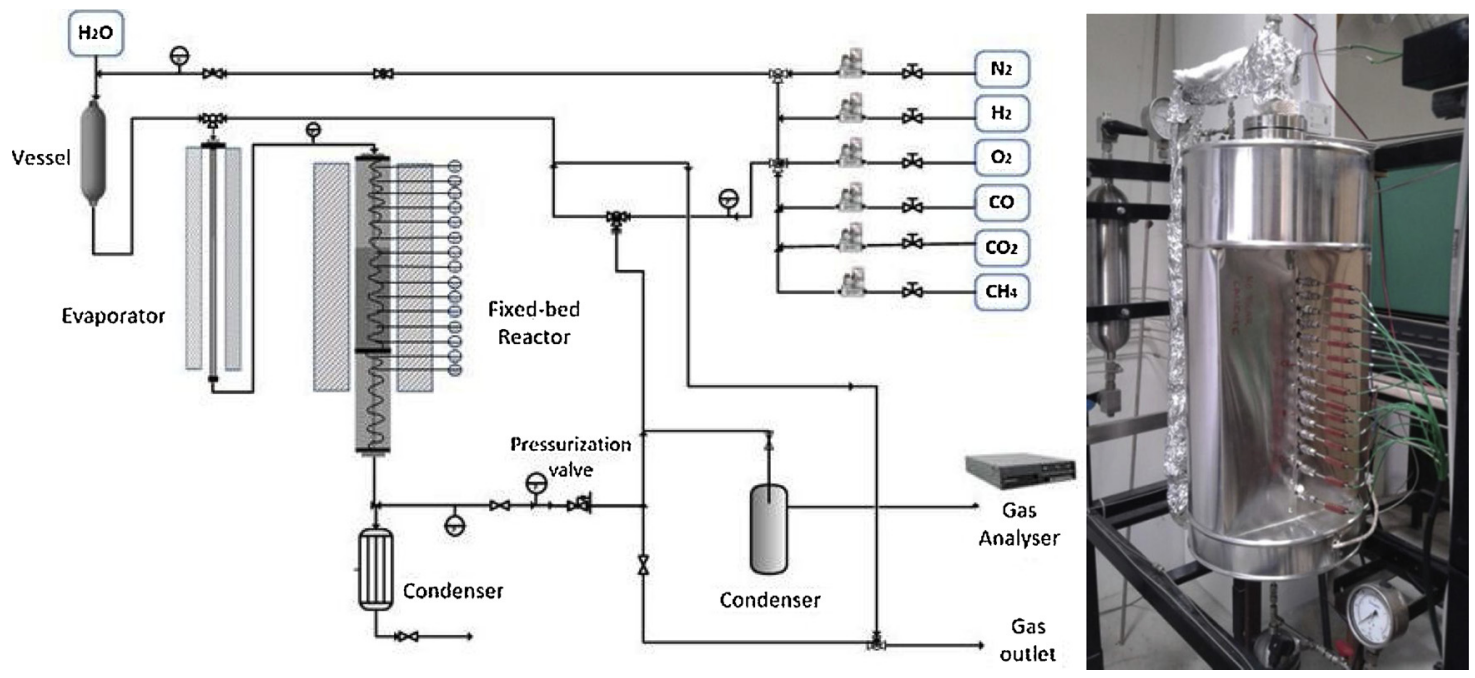

Fig. 2. Schematic (left) and picture (right) of the lab-scale fixed bed reactor rig at ICB-CSIC. 

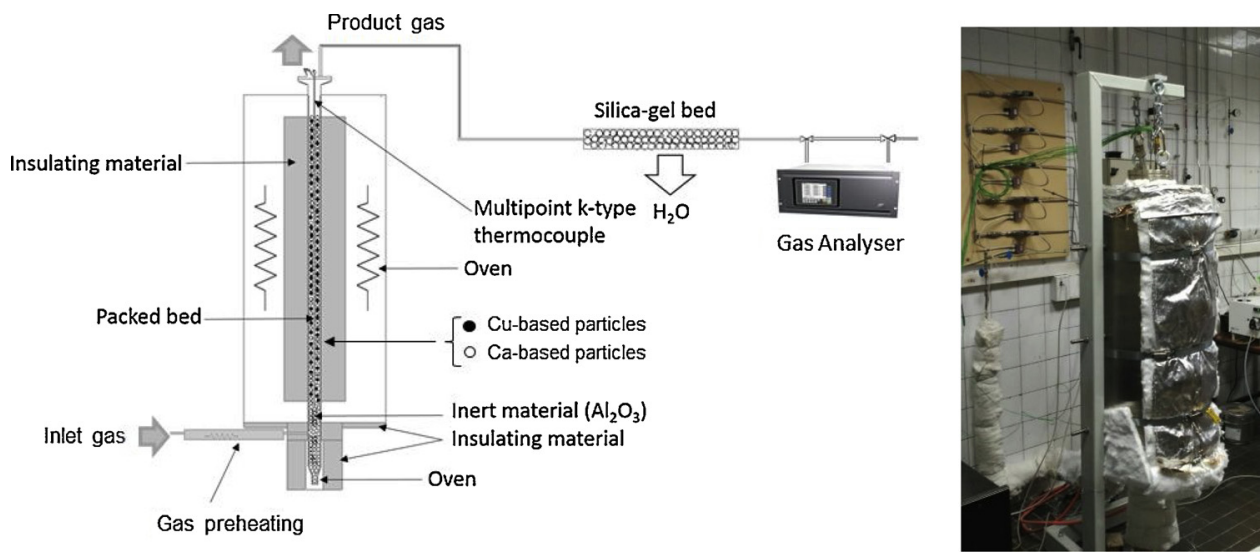

Fig. 3. Schematic of the lab-scale packed bed reactor at INCAR-CSIC.

atmospheric pressure. In this facility, the feasibility of the oxidation and the $\mathrm{CaCO}_{3}$ calcination/CuO reduction stages was assessed, using commercial Cu-based material (i.e., 65 wt.\% $\mathrm{CuO}$ over $\mathrm{SiO}_{2}$ ) and $\mathrm{CO}_{2}$ sorbent (i.e., $98 \mathrm{wt} . \%$ of $\mathrm{CaO}$ ) as functional materials for the experiments. A homogeneous solid mixture of about $1000 \mathrm{~g}$ was loaded in this reactor, varying the proportion between the Cu-based material and the $\mathrm{CO}_{2}$ sorbent to analyse the effect of the solid composition on the performance. Both solids were crushed and sieved until an average particle diameter of around $3 \mathrm{~mm}$ was achieved.

Finally, the packed-bed setup located at the Eindhoven University of Technology (TU/e, The Netherlands) was used for demonstrating the feasibility of the overall process at TRL5. A schematic overview of this experimental device is illustrated in Fig. 4. The tubular packed bed reactor $(1.6 \mathrm{~m}$ long, outer and inner diameters 0.4 and $0.063 \mathrm{~m}$, respectively) was designed and built by Array Industries BV to operate at temperatures of up to $1200{ }^{\circ} \mathrm{C}$ and pressures of up to 10 bar without external heat supply. The solids are loaded in an Inconel tube with a wall thickness of $6 \mathrm{~mm}$, which is surrounded by insulation material to reduce the heat losses. An outer carbon steel reactor wall allows the operation at high pressures. The reactor wall is heated with tracers at $300{ }^{\circ} \mathrm{C}$ to minimize the heat losses. A scheme of the reactor cross-section is represented in Fig. 5. As appreciated in this scheme, there is a tube $(0.7 \mathrm{~m}$ long, and outer diameter of $0.014 \mathrm{~m})$ inside the reactor with 20 K-type thermocouples to measure the axial temperature inside the bed. The thermocouples are protected by an Inconel layer of $2 \mathrm{~mm}$.

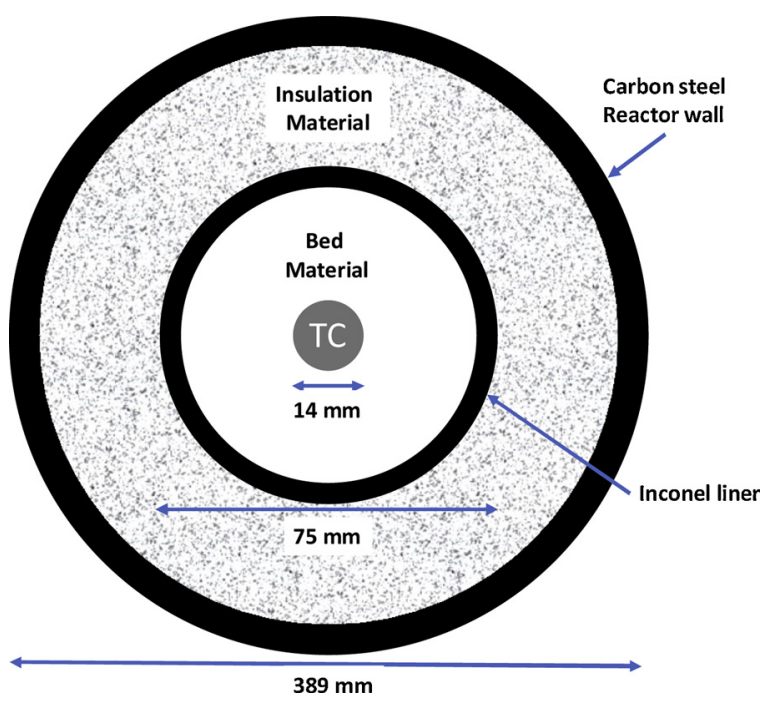

Fig. 5. Schematic overview of the TU/e reactor cross section (TC: Thermocouple).

Functional solids are placed in the zone where the axial temperature is monitored (up to $80 \mathrm{~cm}$ ), whereas in the rest of the reactor an inert material (clay granules) has been used. Feed gas flow rate and

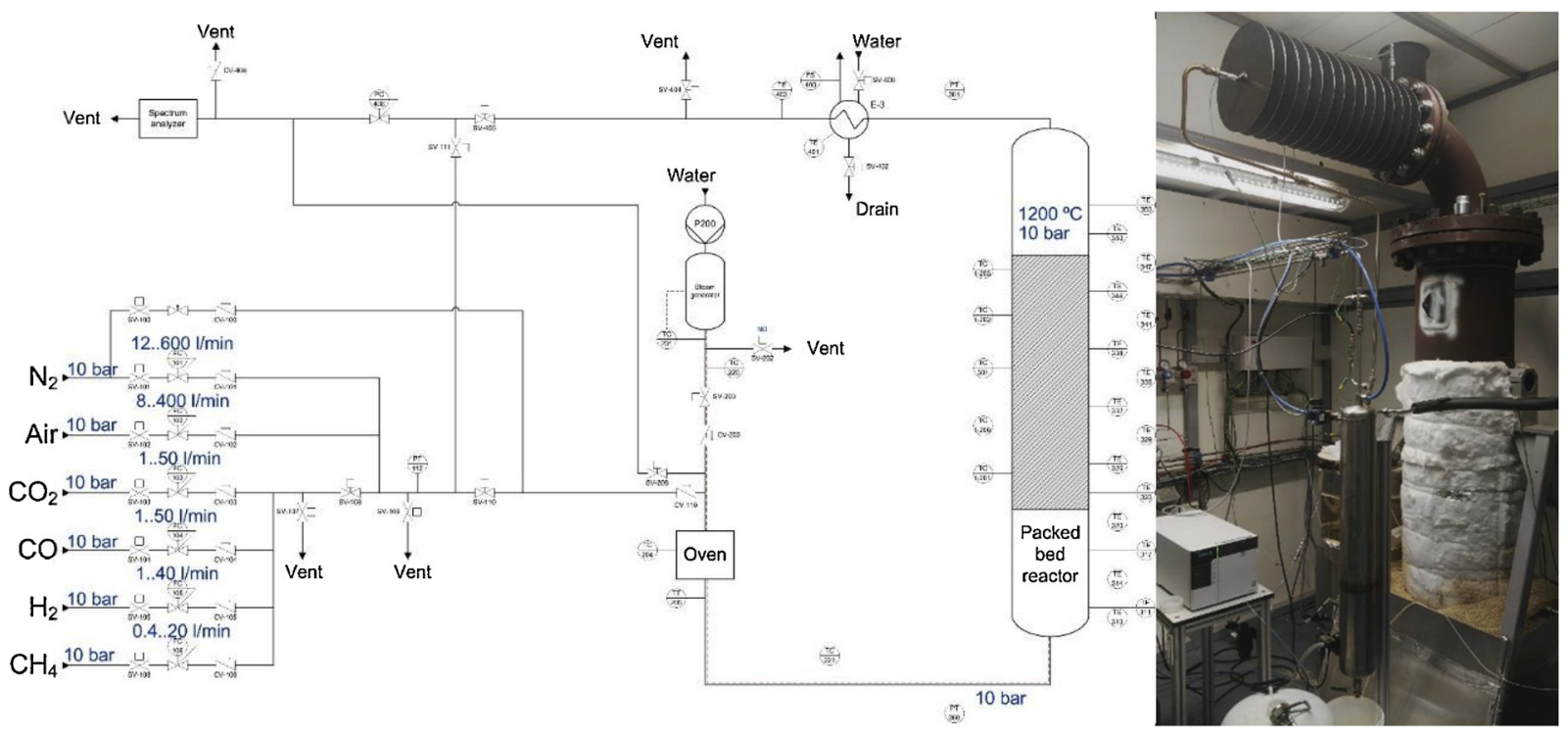

Fig. 4. Schematic of the packed-bed setup at TU/e. 
composition are regulated by the corresponding mass flow controllers. The feed gas is heated up to the desired feed temperature by two electric ovens of $2.2 \mathrm{~kW}$ installed in series (see Fig. 4). To produce steam, demineralized water is pressurized by a HPLC pump and mixed with the other gases in the oven. High-temperature tracers surrounding the pipe between the oven and the reactor maintain the temperature before the gas stream is fed into the reactor.

The product gas is cooled through an air cooler, where steam is removed from the gas phase. The operating pressure in the reactor is controlled by a digital back pressure regulator. Finally, the dried gas is sent to an infrared SICK analyser and an $\mathrm{O}_{2}$ paramagnetic analyser (Siemens Ultramat 23) connected in parallel. The residence time of the gas circulating along the lines, ovens and coolers is about $1 \mathrm{~min}$, which is subtracted from the experimental data. All the setup is automated and can be run $24 \mathrm{~h}$ per day for more than 500 cycles. In this setup, complete $\mathrm{Ca}-\mathrm{Cu}$ looping cycles have been performed under different operation conditions. The three functional materials required for the process were therefore introduced in the reactor. The bed was loaded with a combination of commercial Ni-based catalyst (HiFUEL) supplied by Johnson Matthey, a CaO-based solid from Carmeuse ( $99 \%$ of $\mathrm{CaO}$ ) and the same commercial Cu-based material used at the ICB-CSIC rig (i.e., $72 \%$ wt. $\mathrm{CuO}$ on $\mathrm{Al}_{2} \mathrm{O}_{3}$ ). Solid bed composition was calculated to have $4 \mathrm{wt} . \%$ of $\mathrm{Ni}$ inside the bed and a $\mathrm{Cu} / \mathrm{CaO}$ molar ratio of 2.1 . The particle size of all the solids was around $0.003 \mathrm{~m}$.

Table 1 summarises the operating conditions used in the described facilities for the validation of each stage of the Ca-Cu process, which is described in the following paragraphs.

\subsection{Validation of sorption enhanced reforming (SER) stage}

The feasibility of the SER stage was first demonstrated at the ICBCSIC facility using commercial Ni-based catalyst and synthetic $\mathrm{CaO} /$ $\mathrm{Ca}_{12} \mathrm{Al}_{14} \mathrm{O}_{33}$ sorbent (Grasa et al., 2017). The operation was carried out at $650{ }^{\circ} \mathrm{C}$, at pressures between 3 and $9 \mathrm{bar}, \mathrm{CH}_{4}$ spatial velocities between 0.75 and $2.5 \mathrm{~kg} \mathrm{CH}_{4} \mathrm{~h}^{-1} \mathrm{~kg} \mathrm{cat}^{-1}$ (i.e., up to $0.045 \mathrm{~m} / \mathrm{s}$ ), S/C molar ratios up to 4 and sorbent/catalyst ratios between 4 and 15 . Under these experimental conditions, a gas stream with $\mathrm{H}_{2}$ concentrations between 90 and 94 vol.\% (on a dry basis), less than 6 vol.\% of $\mathrm{CH}_{4}$ and minimum contents ( $<1$ vol.\%) of $\mathrm{CO}$ and $\mathrm{CO}_{2}$ was measured at the packed-bed reactor exit, that is close to the composition given by the SER equilibrium at these conditions. Furthermore, the Ni-based catalyst showed a stable reforming activity after 200 SER-oxidation-reduction/ calcination cycles. A gas stream containing above 90 vol.\% of $\mathrm{H}_{2}$ (on dry basis) was obtained with the aged catalyst operating with space velocities up to $2.5 \mathrm{~kg} \mathrm{CH}_{4} \mathrm{~h}^{-1} \mathrm{~kg}$ cat $^{-1}$, which demonstrated the feasibility of the material for the future scale-up of the $\mathrm{Ca}$ - $\mathrm{Cu}$ process (Grasa et al., 2017; Navarro et al., 2017). In a subsequent work, and for the same $\mathrm{CH}_{4}$ space velocity of $2.5 \mathrm{~kg} \mathrm{CH} \mathrm{CH}_{4}^{-1} \mathrm{~kg}^{-1}$, a barely

\section{Table 1}

Summary of the main operating conditions tested in each packed bed reactor facility.

\begin{tabular}{|c|c|c|c|}
\hline & ICB-CSIC & INCAR-CSIC & $\mathrm{TU} / \mathrm{e}$ \\
\hline \multicolumn{4}{|l|}{$\underline{\text { SER stage }}$} \\
\hline $\mathrm{S} / \mathrm{C}$ molar ratio $[-]$ & 3,4 & & $3,4,5$ \\
\hline Pressure $[\mathrm{bar}]$ & $3-10$ & & $2-7$ \\
\hline $\mathrm{CH}_{4}$ spatial velocity $\left[\mathrm{kg}_{\mathrm{CH} 4} / \mathrm{h} \cdot \mathrm{kg}_{\text {cat }}\right]$ & 2.5 & & 1.7 \\
\hline \multicolumn{4}{|l|}{ Oxidation stage } \\
\hline $\mathrm{O}_{2}$ inlet concentration [vol.\%] & 5 & 3 & $3,5,10$ \\
\hline Pressure $[$ bar $]$ & 10 & 1 & $2-7$ \\
\hline Gas velocity $[\mathrm{m} / \mathrm{s}]$ & 0.04 & 1.6 & $0.3-1$ \\
\hline \multicolumn{4}{|l|}{ Reduction/calcination stage } \\
\hline $\begin{array}{l}\text { Inlet gas mixture [vol.\%] (being } \mathrm{N}_{2} \\
\text { the remaining gas) }\end{array}$ & $\begin{array}{l}58 / 29 / 13 \\
\mathrm{H}_{2} / \mathrm{CH}_{4} / \mathrm{CO}\end{array}$ & $\begin{array}{l}40 / 10 \text { and } 30 / \\
20 \mathrm{H}_{2} / \mathrm{CO} \\
100 \mathrm{CH}_{4}\end{array}$ & $\begin{array}{l}20 / 40 / \\
60 \mathrm{H}_{2}\end{array}$ \\
\hline Pressure [bar] & 1 & 1 & 2 \\
\hline
\end{tabular}

constant gas composition was obtained for the system equal to about 93.5 vol. $\% \mathrm{H}_{2}, 5.8$ vol. $\% \mathrm{CH}_{4}$ and less than 1 vol. $\%$ of $\mathrm{CO}$ and $\mathrm{CO}_{2}$ (on a dry basis), which corresponded to the equilibrium at 10 bar and steamto-carbon molar ratio of 3 (Díez-Martín et al., 2018b).

The validation of this SER stage has been also conducted at the TU/e large-scale facility shown in Fig. 4 through multi-cycle testing. This stage has been studied at $6500^{\circ} \mathrm{C}$ keeping a constant $\mathrm{CH}_{4}$ flow rate of 4 $\mathrm{Nl} /$ min, which corresponds to $1.7 \mathrm{~kg} \mathrm{CH}_{4} \mathrm{~h}^{-1} \mathrm{~kg}^{-1}$ and varying the steam flow rate for keeping a $\mathrm{S} / \mathrm{C}$ ratio between 3 and 5 . Operating pressure was modified between 2 and 7 bar for these tests. The results obtained in this facility corroborated those obtained at smaller scale. SER equilibrium was reached during the operation of this hydrogen production stage, and $\mathrm{H}_{2}$ contents of $97.5 \mathrm{vol} . \%$ (in dry basis) were reached when operating with $\mathrm{S} / \mathrm{C}=5$ at 2 bar. When the operating pressure increased up to $7 \mathrm{bar}$, the $\mathrm{H}_{2}$ content in the product gas decreased to $93.5 \mathrm{vol} . \%$ due to the negative impact of this operating variable on the SER equilibrium (Fernández et al., 2012a). Gas composition stabilised at $93.6 \mathrm{vol} . \% \mathrm{H}_{2}, 5.9 \mathrm{vol} . \% \mathrm{CH}_{4}, 0.17 \mathrm{vol} \% \mathrm{CO}$ and $0.33 \mathrm{vol} . \% \mathrm{CO}_{2}$ (in dry basis) when operating with $\mathrm{S} / \mathrm{C}=3$ at 7 bar, which practically matches the composition obtained at ICB-CSIC for similar conditions (i.e. S/C $=3$ and 10 bar) as depicted in Fig. 6. Differences observed in the duration of the pre-breakthrough are due (mainly) to the different $\mathrm{CO}_{2}$ carrying capacities of the CaO-based synthetic sorbents used in each facility.

\subsection{Validation of $\mathrm{Cu}$ oxidation stage}

The viability of this stage has been experimentally validated at the ICB-CSIC lab-scale rig (Díez-Martín et al., 2018b) and at TRL4 in the INCAR-CSIC facility (Alarcón et al., 2017). Additional tests at TRL5 have been performed at the TU/e facility, which have not been yet published in the literature. As widely reported, the oxidation of $\mathrm{Cu}$ to $\mathrm{CuO}$ is a very exothermic reaction and, therefore, restricted conditions of initial temperatures and $\mathrm{O}_{2}$ concentration in the feed (below 5 vol.\%) are required to avoid overheating during the operation at temperatures beyond $830-850^{\circ} \mathrm{C}$ (Fernández et al., 2014).

During the oxidation tests performed at the INCAR-CSIC rig, a flow rate of $30 \mathrm{Nl} / \mathrm{min}$ containing $3 \mathrm{vol} \%$ of $\mathrm{O}_{2}$ in $\mathrm{N}_{2}$ was fed into the packed bed, which initially contained around $20-25 \mathrm{wt} . \%$ of $\mathrm{Cu}$ (Alarcón et al., 2017). Oxidation experiments were carried out at atmospheric pressure. Both the inlet gas and the solids bed were preheated up to $400{ }^{\circ} \mathrm{C}$. Even at this low initial temperature and low $\mathrm{O}_{2}$ content in the gas, the $\mathrm{Cu}$ oxidation was observed to be significantly fast taking place in narrow reaction fronts throughout the reactor. The low $\mathrm{O}_{2}$ content made the oxidation front advance at lower velocity than the heat exchange front. At these circumstances, the $\mathrm{O}_{2}$ reached the reaction zone at relatively low temperature (i.e., at about $400{ }^{\circ} \mathrm{C}$ ), while the heat generated during the oxidation was absorbed downstream by the solids located between the oxidation and heat exchange fronts. The maximum temperature measured during the operation was around $800{ }^{\circ} \mathrm{C}$, which should prevent the agglomeration or sintering of the $\mathrm{Cu}$ based material and diminish the loss of $\mathrm{CO}_{2}$ by partial decomposition of the CaO-based sorbent. Full $\mathrm{O}_{2}$ conversion was achieved despite the very low $\mathrm{O}_{2}$ concentration in the feed and the high gas velocity (around $1.6 \mathrm{~m} / \mathrm{s}$ at $800^{\circ} \mathrm{C}$ ) and virtually pure $\mathrm{N}_{2}$ was obtain as product gas.

Díez-Martín et al. (2018b) carried out the $\mathrm{Cu}$ oxidation stage by feeding $114 \mathrm{Nl} / \mathrm{h}$ of gas containing $5 \mathrm{vol} . \% \mathrm{O}_{2}$ (in $\mathrm{N}_{2}$ ). The operation was accomplished at $10 \mathrm{bar}$, preheating the solid bed and the feed gas to $725^{\circ} \mathrm{C}$. The combination of high pressure operation and reduced gas flow rate fed into the packed bed at the ICB-CSIC facility resulted in a limited gas velocity during the oxidation tests (i.e. $0.04 \mathrm{~m} / \mathrm{s}$ ). This reduced gas velocity is far from the value of around $1.6 \mathrm{~m} / \mathrm{s}$ achieved in the INCAR-CSIC facility, which makes the oxidation results obtained in both facilities be non-comparable. Due to the relatively high heat loss inherent to the ICB-CSIC experimental setup, significantly lower increases in temperature in the solids bed were observed (of only around 

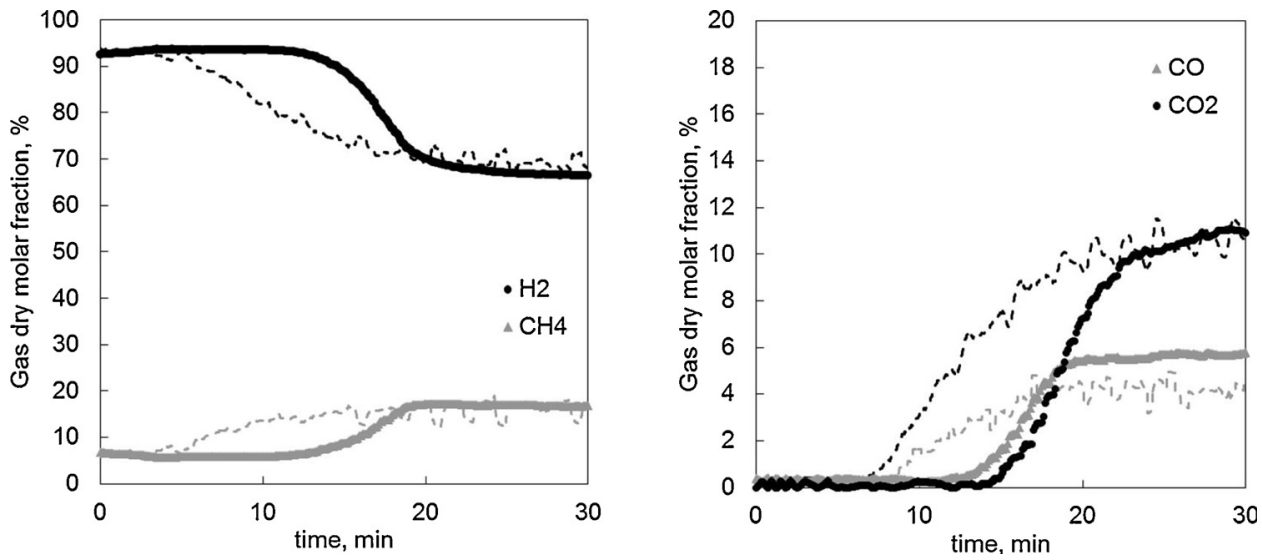

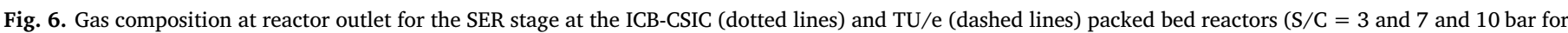
the TU/e and ICB-CSIC facilities, respectively).

$70{ }^{\circ} \mathrm{C}$ ) with absence of a heat plateau during the advance of both oxidation and heat exchange fronts.

In the experimental campaign carried out in the packed-bed reactor at TU/e, a total flowrate of $100 \mathrm{Nl} / \mathrm{min}$ was used for the $\mathrm{Cu}$ oxidation tests varying the $\mathrm{O}_{2}$ concentration in the feed gas between 3,5 and 10 vol. $\% \mathrm{O}_{2}$ in $\mathrm{N}_{2}$. Total pressure was also modified between 2 and 7 bar using a temperature of around $650{ }^{\circ} \mathrm{C}$ for the inlet feed gas. At both pressures, when increasing the $\mathrm{O}_{2}$ concentration in the feed gas, the maximum temperature reached within the solid bed increased due to the increase in the reaction front velocity, which approaches the heat front velocity. Operating with an $\mathrm{O}_{2}$ concentration in the feed of $10 \mathrm{vol}$. $\%$, a maximum value of $840{ }^{\circ} \mathrm{C}$ was reached at an operating pressure of $2 \mathrm{bar}$ and a maximum value of $810^{\circ} \mathrm{C}$ at $7 \mathrm{bar}$. With concentrations of 5 vol. $\%$ of $\mathrm{O}_{2}$, maximum temperatures of around $800{ }^{\circ} \mathrm{C}$ and $780{ }^{\circ} \mathrm{C}$ at 2 bar and 7 bar, respectively, were obtained. The decrease in the maximum temperature reached within the solid bed as the operating pressure is raised is due to the reduction of the total gas velocity, and so of the reaction and heat front velocities. Experiments performed at the TU/e reactor at 2 bar allowed working with a gas velocity of around $1 \mathrm{~m} / \mathrm{s}$ (calculated at an average temperature of $800^{\circ} \mathrm{C}$ ), which is in the order of the gas velocity reached at the INCAR-CSIC reactor. Fig. 7 shows the gas concentration profile obtained at TU/e reactor outlet at 2 bar and with 3 vol. $\% \mathrm{O}_{2}$ in the feed gas. As noticed, full $\mathrm{O}_{2}$ conversion was reached at this stage despite of the very low $\mathrm{O}_{2}$ content in the feed gas since only $\mathrm{CO}_{2}$ and $\mathrm{N}_{2}$ were measured at the outlet. These results

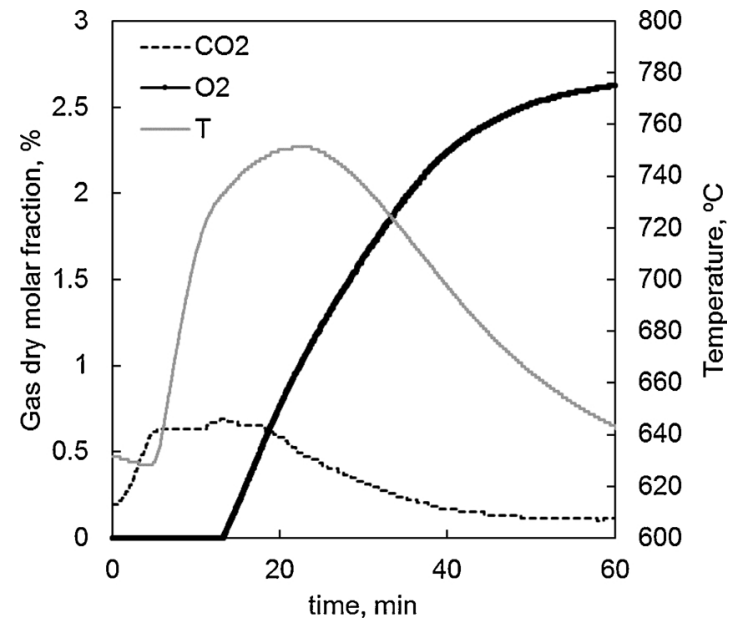

Fig. 7. Gas composition and temperature at reactor outlet for the oxidation stage at TU/e packed bed reactor facility operating at 2 bar with 3 vol. $\% \mathrm{O}_{2}$ in the feed gas. confirmed the behaviour observed at the INCAR-CSIC facility for similar conditions of gas velocity and $\mathrm{O}_{2}$ content in the feed gas, despite of the lower maximum temperature reached within the solid bed in this case (i.e. around $750{ }^{\circ} \mathrm{C}$ ). Based on the calculation of the $\mathrm{O}_{2}$ consumed during this stage, it could be concluded that full oxidation of the $\mathrm{Cu}$ present in the solid bed into $\mathrm{CuO}$ occurred during the oxidation tests.

\subsection{Validation of $\mathrm{CaCO}_{3}$ calcination/CuO reduction stage}

In the facility located at ICB-CSIC, the reduction/calcination stage was studied using a fuel gas with 58 vol. $\% \mathrm{H}_{2}, 29$ vol. $\% \mathrm{CH}_{4}$ and 13 vol. $\%$ CO (without accounting for $\mathrm{N}_{2}$ ) (Díez-Martín et al., 2018b). This fuel gas composition corresponds to that calculated by Fernández and Abanades (2017c) for a gas stream resulting from the mixing of a gas produced in a separate SMR stage and the off-gas obtained from a hydrogen purification unit (PSA). A gas flow of $0.9 \mathrm{Nl} / \mathrm{min}$ was fed to the reactor, which was previously heated up to a sufficiently high temperature $825{ }^{\circ} \mathrm{C}$ to compensate the heat losses to the ambient and for carrying out the tests without operating the electric resistance. Under these conditions, the reaction and heat exchange fronts evolved together through the reactor, resulting in a maximum temperature of $852^{\circ} \mathrm{C}$, which was sufficiently high to fulfil complete decomposition of the $\mathrm{CaCO}_{3}$ present in the solid bed. During the breakthrough period, the evolution of both $\mathrm{H}_{2}$ and $\mathrm{CO}$ curves at the reactor exit were similar, showing a maximum value when the CuO-based particles approach total conversion, followed by a progressive reduction of the concentration until relatively low values for $\mathrm{H}_{2}$ and $\mathrm{CO}$ were achieved. In contrast, the concentration of $\mathrm{CH}_{4}$ during the breakthrough gradually increased but at a slower velocity than $\mathrm{CO}$ and $\mathrm{H}_{2}$. This phenomenon may occur due to the partial decomposition of $\mathrm{CH}_{4}$ into $\mathrm{H}_{2}$ and carbon and the reverse WGS reaction catalysed by the Ni- and Cu-based materials, respectively (Borghei et al., 2010; Snoeck et al., 2002; Zhou et al., 2013).

Reduction/calcination experiments were also performed at INCARCSIC, in which different gas mixtures were used as fuel gas, such as $\mathrm{H}_{2}$ diluted in $\mathrm{N}_{2}, \mathrm{H}_{2} / \mathrm{CO}$ mixtures and pure $\mathrm{CH}_{4}$. Before each reduction/ calcination test, a stream of pure $\mathrm{CO}_{2}$ at $600{ }^{\circ} \mathrm{C}$ was passed through the solids bed to partially carbonate the $\mathrm{CaO}$-based $\mathrm{CO}_{2}$ sorbent, thus ensuring the appropriate ratio of $\mathrm{CuO}$ and $\mathrm{CaCO}_{3}$ depending on the fuel gas composition. The $\mathrm{CuO} / \mathrm{CaCO}_{3}$ molar ratio present in the bed was between 1.6 and 3.2, which should be sufficiently high to carry out the reduction/calcination avoiding additional energy supply (Alarcón and Fernández, 2015) (i.e., the oven was used exclusively for compensating the reactor heat losses). In a first work, a flowrate of $15 \mathrm{Nl} / \mathrm{min}$ ( $50 \mathrm{vol}$. $\%$ of $\mathrm{H}_{2}$ in $\mathrm{N}_{2}$ ) at $400{ }^{\circ} \mathrm{C}$ was used as reducing gas (Fernández et al., 2016). It was observed a rapid increase in the temperature profile as the $\mathrm{CuO}$ reduction progressed due to the great reactivity of the CuO-based 

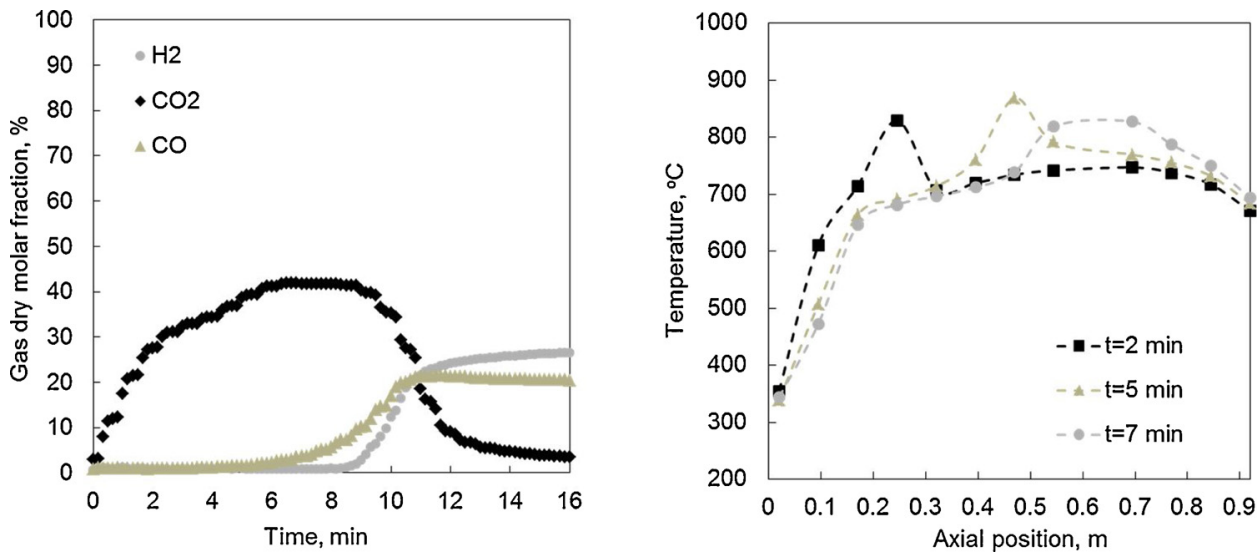

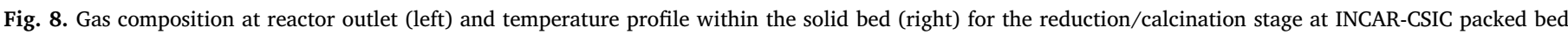
reactor facility with $20 \mathrm{vol} . \% \mathrm{CO}$ and $30 \mathrm{vol} . \% \mathrm{H}_{2}$ in the feed gas.

material with $\mathrm{H}_{2}$ even at moderate temperatures. While the maximum temperatures achieved in the bed were below $800^{\circ} \mathrm{C}, \mathrm{CaCO}_{3}$ calcination was impeded and very low $\mathrm{CO}_{2}$ concentrations were measured at the reactor exit (i.e., below 1 vol.\%). Only when temperatures of around $900^{\circ} \mathrm{C}$ were reached, an increasing $\mathrm{CO}_{2}$ concentration at the reactor outlet of up to 40 vol.\% (dry basis) was observed, as a result of a fast $\mathrm{CaCO}_{3}$ calcination. During the pre-breakthrough period, the $\mathrm{H}_{2}$ fed to the reactor achieved almost complete conversion (only $\mathrm{CO}_{2}$ was detected in the dry product gas) and during the breakthrough (3-4 min) the $\mathrm{H}_{2}$ concentration rapidly increased until it reached the inlet value due to the high reactivity of $\mathrm{CuO}$ with $\mathrm{H}_{2}$.

In other experiments, mixtures of up to 20 vol. $\%$ of $\mathrm{CO}$ in $\mathrm{H}_{2}$ were used as feed gas for the reduction/calcination process (Alarcón et al., 2017), which also served to demonstrate the good reactivity of $\mathrm{CuO}$ with these gases. Fig. 8 shows the outlet gas concentration and temperature profile obtained for the test with $20 \mathrm{vol} . \% \mathrm{CO}$ and $30 \mathrm{vol} . \% \mathrm{H}_{2}$ in the feed gas for the INCAR-CSIC facility. As shown in this figure, temperature profiles of about $880^{\circ} \mathrm{C}$ were achieved that allowed the complete conversion of the fuel gas. An increasing amount of $\mathrm{CO}$ was observed at reactor outlet during the breakthrough period, indicating the presence of the reverse WGS reaction that was enhanced by the high temperature and the high concentration of $\mathrm{CO}_{2}$ in the reactor. Finally, the reduction/calcination stage using pure $\mathrm{CH}_{4}$ as fuel gas has been recently tested (Fernández et al., 2018; Fernández and Abanades, 2019). Poor reactivity of the $\mathrm{CuO}$ with $\mathrm{CH}_{4}$ was observed by feeding flowrates between 2 and $4 \mathrm{Nl} / \mathrm{min}$ of $\mathrm{CH}_{4}$ at $620^{\circ} \mathrm{C}$, which resulted in reduced temperature increase within the reactor compared to the experiments with $\mathrm{H}_{2}$ and $\mathrm{CO}$. The reactivity of $\mathrm{CH}_{4}$ with $\mathrm{CuO}$ was especially modest at temperatures below $750{ }^{\circ} \mathrm{C}$. Additional experiments with higher initial bed temperatures showed that solid bed temperatures of about $800{ }^{\circ} \mathrm{C}$ were needed to convert almost completely the inlet $\mathrm{CH}_{4}$ fed (i.e., below 3 vol.\% of $\mathrm{CH}_{4}$ was measured at reactor outlet) and have virtually pure $\mathrm{CO}_{2}$ (on a dry basis) in the outlet gas. Temperature profiles above $900{ }^{\circ} \mathrm{C}$ were then obtained, which facilitated the calcination of $\mathrm{CaCO}_{3}$. Once the $\mathrm{Cu}$-based particles approached total reduction, the $\mathrm{CH}_{4}$ concentration in the outlet gas increased and the high temperatures registered in the bed also promoted the SMR, WGS and carbon gasification reactions, giving rise to significant amounts of $\mathrm{H}_{2}$ and $\mathrm{CO}$ in the outlet gas during the breakthrough period.

\subsection{Multi-cycle operation feasibility}

The feasibility of consecutive Ca-Cu looping cycles was first experimentally demonstrated in the packed-bed reactor located at ICBCSIC under relevant conditions for the process at large scale (DíezMartín et al., 2018b). During the successive SER stages (carried out with $\mathrm{S} / \mathrm{C}$ molar ratio of 3 , at $650{ }^{\circ} \mathrm{C}$ and $10 \mathrm{bar}$ ), the $\mathrm{CO}_{2}$ sorbent maintained a relatively constant $\mathrm{CO}_{2}$ carrying capacity of $0.35 \mathrm{~g}_{\mathrm{CO} 2} / \mathrm{g}$ calcined sorbent. Due to the heat losses, the maximum temperature achieved in the carbonation front (about $720^{\circ} \mathrm{C}$ ) was slightly lower than the theoretical value predicted by the PHM reactor models in the literature (Fernández and Abanades, 2017c; Martini et al., 2017). Almost pure $\mathrm{H}_{2}$ was produced during the pre-breakthrough period and once the $\mathrm{CO}_{2}$ sorbent was fully carbonated (post-breakthrough), it was observed that $\mathrm{CO}$ and $\mathrm{H}_{2}$ concentrations stabilized above the corresponding SMR equilibrium values whereas $\mathrm{CH}_{4}$ concentration stabilized below SMR equilibrium. These results are due to the presence of reduced Cu-based solids, which favour the thermal cracking of a fraction of the $\mathrm{CH}_{4}$ fed into the reactor into $\mathrm{C}$ and $\mathrm{H}_{2}$, and then the gasification of the C formed takes place to form CO (Díez-Martín et al., 2018b). During the subsequent reaction stage, the operating pressure was maintained at $10 \mathrm{bar}$ and diluted air $\left(5 \mathrm{vol} . \% \mathrm{O}_{2}\right)$ preheated at $725^{\circ} \mathrm{C}$ allowed the fast and complete oxidation of both $\mathrm{Cu}$ - and Ni-based solids. A maximum temperature of around $770{ }^{\circ} \mathrm{C}$ was registered, which minimized the loss of $\mathrm{CO}_{2}$ by partial calcination of the $\mathrm{CaCO}_{3}$ formed during the SER step. Nevertheless, higher concentration of $\mathrm{CO}_{2}$ than expected was measured in the product gas (i.e., up to 0.85 vol. $\% \mathrm{CO}_{2}$ instead of 0.013 vol. $\%$ given by the $\mathrm{CaO} / \mathrm{CaCO}_{3}$ equilibrium at $770{ }^{\circ} \mathrm{C}$ and $10 \mathrm{bar}$ ), due to the oxidation of carbon deposited in the bed during the SER operation. The CuO-based material presented high reactivity during the reduction/calcination stages carried out with a mixture of $\mathrm{H}_{2}, \mathrm{CH}_{4}$ and $\mathrm{CO}$, simulating the composition of a PSA off-gas. A CuO/ $\mathrm{CaCO}_{3}$ molar ratio of 2 allowed about $95 \%$ of the $\mathrm{CaCO}_{3}$ present in the bed to be calcined, while obtaining almost pure $\mathrm{CO}_{2}$ (and steam) as product gas. The results obtained during three consecutive cycles were very reproducible demonstrating the stability of the materials.

More recently, the continuous operation of the $\mathrm{Ca}-\mathrm{Cu}$ process was proven at the TU/e packed-bed reactor over 285 SER-oxidation-reduction/calcination cycles. The results of few selected cycles can be seen in Fig. 9 and Table 2. For these cycles, the SER stage was studied at $650{ }^{\circ} \mathrm{C}$ and 2 bar with the $\mathrm{S} / \mathrm{C}$ ratio equal to 3 , whereas for the $\mathrm{Cu}$ oxidation stage the same operating pressure of the SER stage was used for a feed gas containing 5 vol. $\% \mathrm{O}_{2}$. For the reduction/calcination stage, a $\mathrm{H}_{2} / \mathrm{N}_{2}$ fuel gas mixture was used at 2 bar and $6500^{\circ} \mathrm{C}$ with a $\mathrm{H}_{2}$ content of 40 vol.\%. As appreciated from the results shown in Fig. 9 (a), there is a loss in the $\mathrm{CO}_{2}$ carrying capacity of the Ca-based material from $14 \mathrm{~g}_{\mathrm{CO} 2} /$ $\mathrm{g}$ calcined sorbent in cycle 100 to $10 \mathrm{~g} \mathrm{CO} / \mathrm{g}$ calcined sorbent in cycle 185 that makes the pre-breakthrough period to be shortened by $3 \mathrm{~min}$. However, despite of this $\mathrm{CO}_{2}$ carrying capacity loss, the $\mathrm{H}_{2}$ content of the gas produced in this stage remains practically unaltered at around 97.5 vol.\% (dry basis) (Table 2). Regarding the temperature profiles during the SER and reduction stages (Fig. 9), lower maximum temperatures than those predicted by the PHM models in the literature were measured, due to the heat losses to the ambient. Despite all these 


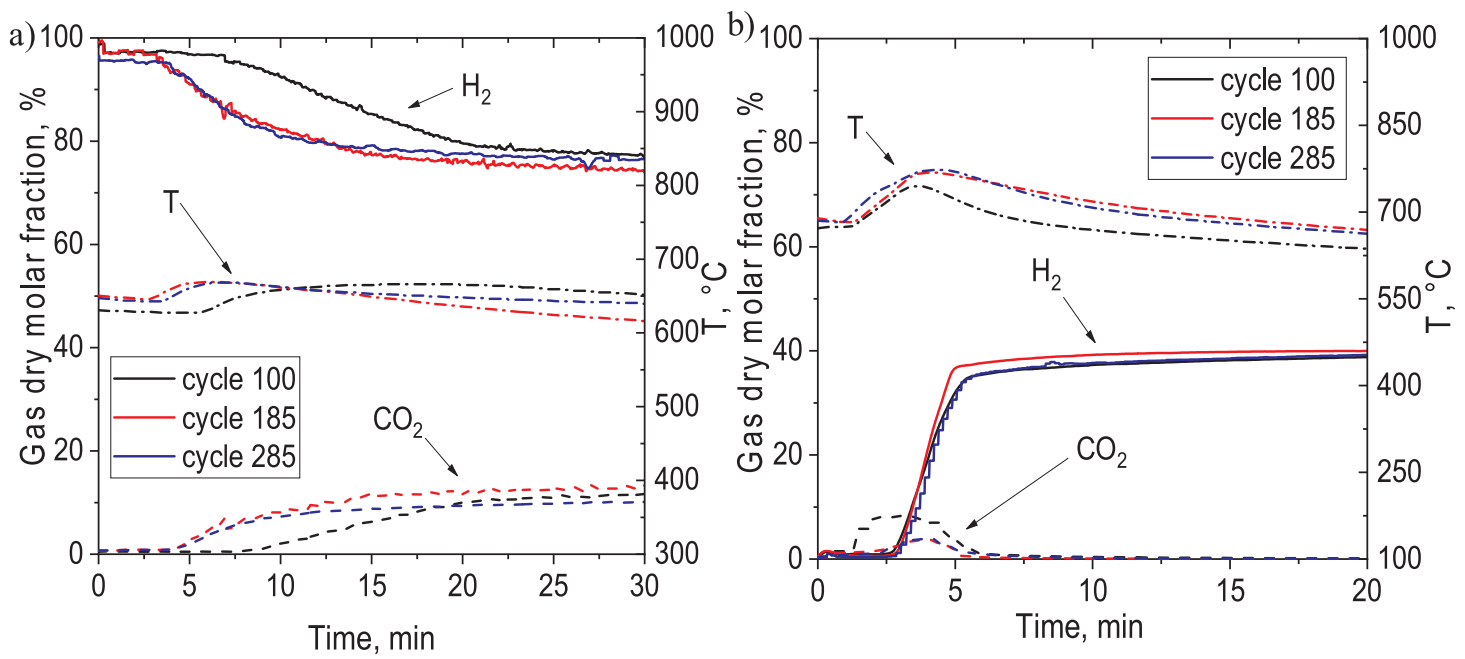

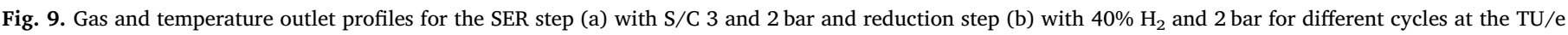
packed-bed reactor.

Table 2

Comparison between different cycles. Conditions SER: S/C = 3, 2 bar, 16 1/min; Conditions reduction: $40 \% \mathrm{H}_{2}, 2$ bar, $100 \mathrm{l} / \mathrm{min}$.

\begin{tabular}{llll}
\hline Cycle number & 100 & 185 & 285 \\
\hline$\% \mathrm{H}_{2}$ during pre-breakthrough in SER & 97.4 & 97.5 & 95.6 \\
Pre-breakthrough time in SER [min] & 8 & 5 & 5 \\
$\mathrm{~T}_{\text {max,out }}$ in SER $\left[{ }^{\circ} \mathrm{C}\right]$ & 666 & 669 & 668 \\
Pre-breakthrough time in reduction/calcination [min] & 3 & 3 & 3 \\
$\mathrm{~T}_{\text {max,out }}$ in reduction/calcination $\left[{ }^{\circ} \mathrm{C}\right]$ & 760 & 773 & 772 \\
\hline
\end{tabular}

facts, the functional materials introduced into the packed-bed reactor still performed well after this high number of cycles, where the results for each of the individual reaction stages proved highly reproducible. The high reproducibility along the multiple consecutives cycles carried out demonstrates the good stability of the performance of the materials tested.

\section{Process design of $\mathrm{Ca}-\mathrm{Cu}$ looping based plants for industrial applications}

\subsection{Standalone hydrogen production plants}

The application of the $\mathrm{Ca}-\mathrm{Cu}$ looping process having received more attention in the literature is the production of high purity $\mathrm{H}_{2}$ as a standalone plant, due to its good performance in terms of hydrogen production efficiency and reduced $\mathrm{CO}_{2}$ emissions. A series of fixed bed reactors is the process configuration proposed for this application since it allows pressure swing between the high pressure hydrogen production stage and the low pressure $\mathrm{CaCO}_{3}$ regeneration step.

The performance of a large scale hydrogen production plant based on a Ca-Cu process was evaluated for the first time by Martínez et al. (2014) who proposed the reactors system depicted in Fig. 10. These authors considered as a starting point for the Ca-Cu looping scheme that described by Fernández et al. (2012c), where the three main reaction stages indicated in Fig. 1 were completed with two additional ones: (1) an intermediate heating stage right after completing the $\mathrm{Cu}$ oxidation and before the calcination/reduction stage, using as heating source the $\mathrm{O}_{2}$-depleted gas recirculated from $\mathrm{Cu}$ oxidation outlet, and (2) a cooling stage by means of the endothermic reforming of additional $\mathrm{CH}_{4}$ or natural gas right after the calcination/reduction process. All the reaction steps in the $\mathrm{Ca}-\mathrm{Cu}$ looping process were calculated using the simplified approach described by Fernández et al. (2012c). As shown in Fig. 10, intermediate stages of rinsing, pressurization and depressurization were also included in the analysis by Martínez et al. (2014). Moreover, the desulphurisation of the natural gas considered as a feedstock to the process, as well as the pre-reforming of the desulphurised natural gas to convert the higher hydrocarbons were also included in the process layout and the heat and mass balance calculation.

A total number of 15 reactors was calculated by Martínez et al. (2014) for running a plant with a typical $\mathrm{H}_{2}$ output of $30,000 \mathrm{Nm}^{3} / \mathrm{h}$, corresponding to three reactors operating in parallel in the SER stage, three in the $\mathrm{Cu}$ oxidation stage, three in the heating stage before reduction/calcination, and keeping one reactor for each of the remaining stages (i.e. rinse, depressurisation, pressurisation, calcination/reduction and cooling/reforming stages). Hydrogen production efficiencies as high as $76 \%$ were calculated in this work, including the penalties linked to the electricity import as well as the benefits for the steam exported. Compared with a reference $\mathrm{H}_{2}$ production plant based on the well-established fired tubular reformer (FTR) technology with MDEA for $\mathrm{CO}_{2}$ absorption, the efficiency reached by the $\mathrm{Ca}-\mathrm{Cu}$ looping based plant is around 4\%-points higher than that calculated for the benchmark process. Moreover, global $\mathrm{CO}_{2}$ capture efficiencies estimated were about $94 \%$, which are well above the capture efficiency of $85 \%$ estimated for the benchmark (Martínez et al., 2014).

In a later work, Fernández and Abanades (2017c) evaluated the performance of the $\mathrm{Ca}-\mathrm{Cu}$ looping reactors shown in Fig. 10 under conditions of reduced pressure for the SER stage with the objective of preventing $\mathrm{CaO}$ hydration from occurring in this stage. This work included a more elaborated reactor model for an accurate calculation of the temperature and concentration profiles within each individual stage of the $\mathrm{Ca}-\mathrm{Cu}$ process with respect to the previous work by Martínez et al. (2014). An S/C ratio of 3, an inlet temperature of $700{ }^{\circ} \mathrm{C}$ and an operating pressure of $10 \mathrm{bar}$ for the SER stage were proposed in this work for avoiding $\mathrm{Ca}(\mathrm{OH})_{2}$ formation while obtaining a gas product with a $\mathrm{H}_{2}$ content above 90 vol.\% at this stage outlet. Operating pressure of $\mathrm{Cu}$ oxidation stage was proposed to be raised to $20 \mathrm{bar}$ for limiting the $\mathrm{CO}_{2}$ emissions during this stage. Considering an aspect ratio of 2 for the reactor (i.e., length/diameter $=2$ ), reactor dimensions were estimated considering a maximum pressure drop of $10 \%$ of inlet pressure and the same stage duration of $15 \mathrm{~min}$ for all the $\mathrm{Ca}-\mathrm{Cu}$ stages (i.e., SER, oxidation, heating, reduction/calcination, cooling/reforming). In this way, one reactor of $3 \times 6 \mathrm{~m}$ for each of the Ca-Cu stages would be needed (neglecting the duration of the rinse, pressurization and depressurization stages needed at a larger scale). On the whole, hydrogen production efficiency remained invariable with respect to the value of 76\% previously reported by Martínez et al. (2014).

Recently, a techno-economic analysis of a $\mathrm{H}_{2}$ production plant using 


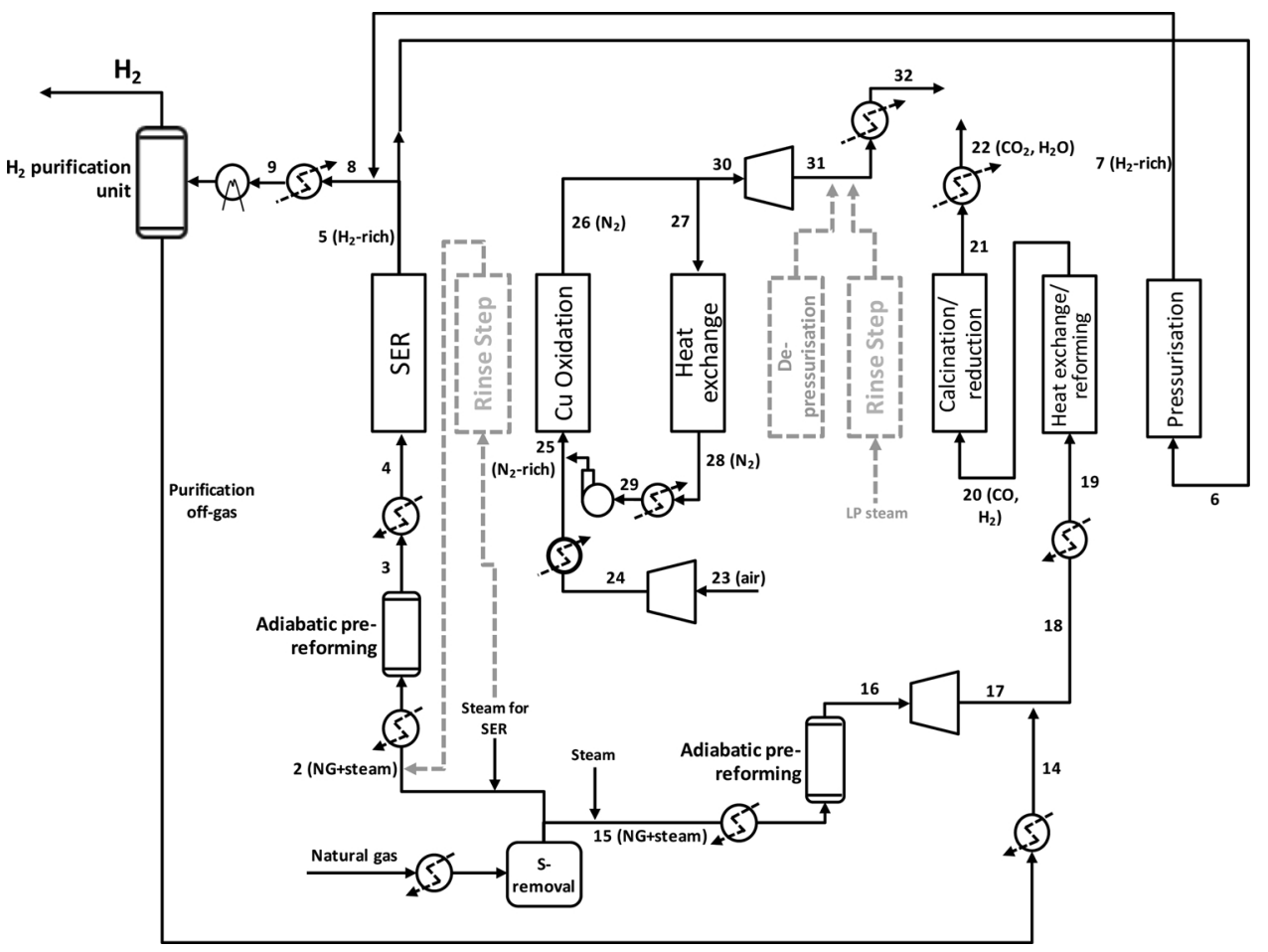

Fig. 10. Scheme of the standalone Ca-Cu based hydrogen plant analysed by Martínez et al. (2014).

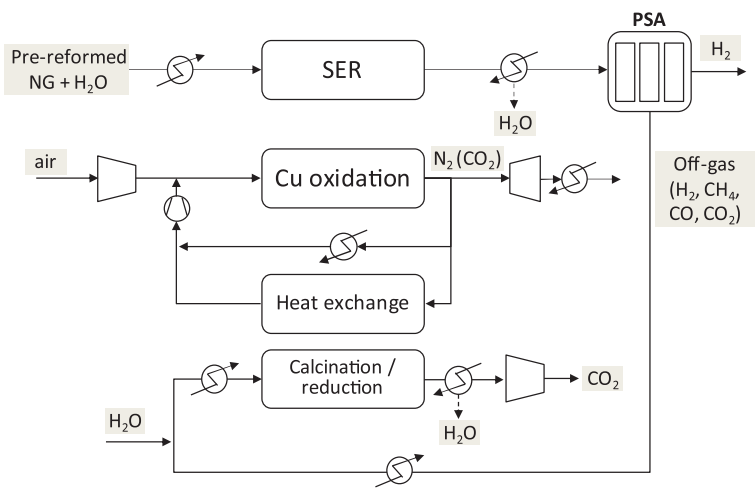

Fig. 11. Scheme of the $\mathrm{Ca}-\mathrm{Cu}$ fixed-bed reactors arrangement avoiding the cooling/reforming stage.

the Ca-Cu looping process has been published by Riva et al. (2018). The reactor layout proposed was simplified with respect to those previously considered and the cooling/reforming stage placed right after the reduction/calcination was avoided, resulting in the scheme shown in Fig. 11. In this process configuration, the off-gas from the purification unit is used as fuel in the calcination/reduction stage and the S/C ratio needed in the SER stage is therefore tuned for avoiding the need of additional fuel for this reduction step. A sharp front model, validated on the dynamic model published by Martini et al. (2016), was used for calculating the fixed bed reactors system. Each reactor was proposed to be divided into 4 sub-reactors with reduced length and diameter while keeping a constant length to diameter ratio of about 2 , to reduce both the pressure drop across the fixed bed reactors and the total volume of the reactors, and therefore the amount of functional materials needed. A sensitivity analysis was performed on the operating pressure of SER and oxidation stages in this work, demonstrating that reducing the operating pressure from 25 bar to 11 bar makes the global hydrogen efficiency to increase up to $79 \%$ when accounting for electricity and steam exchange with the surroundings. On the other hand, lowering the operating pressure leads to larger reactors volume and ultimately higher costs of $\mathrm{H}_{2}$ production and of $\mathrm{CO}_{2}$ avoided. Considering a $\mathrm{H}_{2}$ output of $30,000 \mathrm{Nm}^{3} / \mathrm{h}$, the calculated cost for hydrogen production ranges between 0.178 and $0.181 € / \mathrm{Nm}^{3}$ (operating SER stage at 25 and 11 bar, respectively), which is significantly lower than the calculated cost of $0.194 € / \mathrm{Nm}^{3}$ for the benchmark hydrogen plant with $\mathrm{CO}_{2}$ capture using a MDEA process. The estimated cost of $\mathrm{CO}_{2}$ avoided is between 30 and $37 € / t$, vs. $64 € / t$ of the benchmark.

\subsection{Steel production with reduced $\mathrm{CO}_{2}$ emissions through the $\mathrm{Ca}$-Cu process}

The implementation of $\mathrm{CO}_{2}$ capture technologies on the gas generated in the blast furnace of a steel mill plant has been considered as one of the most promising routes for decarbonising the most common steelmaking route (i.e., blast furnace $(\mathrm{BF})+$ basic oxygen furnace), since this gas contains $60-80 \%$ of the total carbon coming into the steel mill (Romano et al., 2013). Removing these carbon compounds from the $\mathrm{N}_{2}$-rich blast furnace gas (BFG) allows producing a $\mathrm{H}_{2}$-enrinched gas that can be used as 'low-carbon' fuel in the power plant located within the steel mill premises and in the main heating processes of the steel mill (i.e., hot stoves and coke plant). For this specific application, the need of operating the BFG decarbonisation step at high pressure is not mandatory since the BFG is generated at moderate pressure in the $\mathrm{BF}$ and all the applications of this gas as fuel within the steelworks are at nearly atmospheric pressure. Moreover, the production of BFG in a typical BF-based steel mill producing 4 million tons of hot rolled coil (HRC) per year is around $1600 \mathrm{Nm}^{3} / \mathrm{t}_{\mathrm{HRC}}$ (i.e., around $200 \mathrm{Nm}^{3} / \mathrm{s}$ ) (Santos, 2013), which is between 15 and 17 times the flow rate of gas processed in the SER stage of the Ca-Cu based hydrogen production plant of $30,000 \mathrm{Nm}^{3} / \mathrm{h}$ of $\mathrm{H}_{2}$ output analysed in the literature (Fernández and Abanades, 2017c; Martínez et al., 2014; Riva et al., 2018). The operation of a packed-bed reactor system for processing such a big flow rate of BFG in a Ca-Cu looping process would turn the operation at high pressure mandatory to reduce the size of the reactors and so the capital and operational costs of the system. However, the compression of the large flow rate of BFG in this case would be very energy-consuming, penalising the performance of the process.

Therefore, an arrangement of atmospheric fluidised bed reactors has 


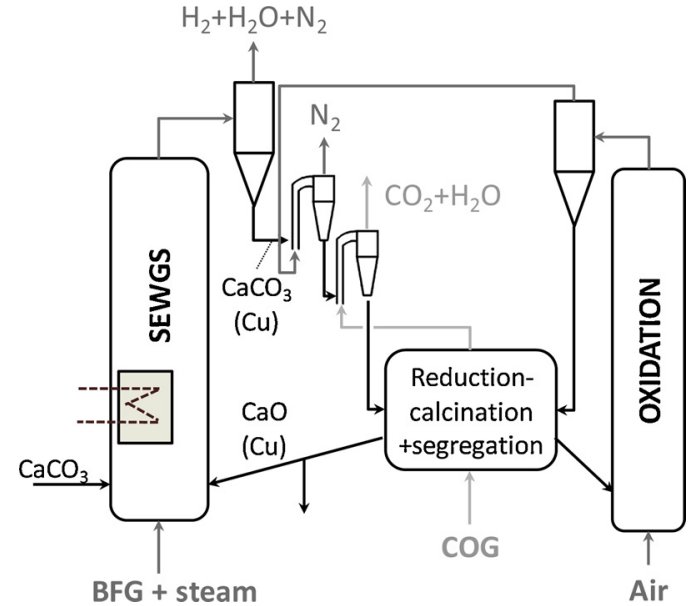

Fig. 12. Scheme of the reactors arrangement for the $\mathrm{Ca}-\mathrm{Cu}$ looping process for $\mathrm{CO}_{2}$ capture from blast furnace gas in steel mills (adapted from Martínez et al. (2018)).

been proposed for operating the $\mathrm{Ca}$ - $\mathrm{Cu}$ process when focused on decarbonising the BFG in a steel mill (Fernández et al., 2017). A simplified scheme of this Ca-Cu process arrangement is shown in Fig. 12. In this reactor configuration, the production of the $\mathrm{H}_{2}$-enrinched gas stage should be carried out in a circulating fluidised bed (CFB) reactor since bringing the huge BFG flow rate into contact with the $\mathrm{CaO}$-rich solids can only be made in this type of reactor with very high gas throughput per unit of cross-sectional area. WGS and $\mathrm{CaO}$ carbonation reactions (Eqs. (2-3)) occur in the hydrogen production step of the Ca-Cu process (i.e., referred to as Sorption Enhanced Water Gas Shift stage, SEWGS in Fig. 12) since BFG does not contain significant amounts of $\mathrm{CH}_{4}$, being mainly composed of $\mathrm{CO}$ and $\mathrm{CO}_{2}$ diluted in $\mathrm{N}_{2}$. In this way, only two functional materials would be needed for running this $\mathrm{Ca}-\mathrm{Cu}$ process configuration, namely the $\mathrm{CaO}$-based $\mathrm{CO}_{2}$ sorbent and the $\mathrm{Cu}$-based oxygen carrier. This reactor configuration allows the introduction of a solid separation step by segregation between the $\mathrm{CaO}$ and the $\mathrm{Cu}$-based particles in the calcination/reduction reactor, which will provide the $\mathrm{CaO}$ needed for the ironmaking process and so will make the conventional lime plant in the steel mill unnecessary, while producing lime with no $\mathrm{CO}_{2}$ emissions. Moreover, the segregation of the particles will improve the performance of the $\mathrm{Ca}-\mathrm{Cu}$ system since it reduces the $\mathrm{Cu}$ based particles amount flowing from the reduction/calcination through the SEWGS reactor, where they act as a thermal ballast. A $\mathrm{N}_{2}$-free gas is needed as fuel in the reduction/calcination step in order to avoid diluting the $\mathrm{CO}_{2}$ generated with $\mathrm{N}_{2}$. The coke oven gas (COG), which is rich in $\mathrm{H}_{2}$ and $\mathrm{CH}_{4}$, is used therefore as feed gas in this stage. Moreover, as indicated in Fig. 12, there is a second hot solid stream fed to the calcination/reduction reactor in this scheme, which comes from an oxidation stage operating at higher temperature that supplies part of the energy needed for the $\mathrm{CaCO}_{3}$ calcination in the calcination/reduction reactor.

This Ca-Cu looping scheme was described for the first time by Fernández et al. (2017) that solved the balances to define the operating conditions window for each stage. The SEWGS reactor is proposed to be operated at $600^{\circ} \mathrm{C}$ with a S/C ratio of 1 . Solids exiting the SEGWS reactor need to be preheated as much as possible before being fed to the calcination/reduction reactor in order to reduce the heat demand in this reactor and so the need of Cu-based material. Operating temperatures for the calcination/reduction and $\mathrm{Cu}$ oxidation reactors were set at $870{ }^{\circ} \mathrm{C}$ and $900{ }^{\circ} \mathrm{C}$, respectively, in order to limit Cu-based material degradation in the oxidation reactor and to have sufficient temperature difference between reactors to supply energy through circulating solids cooling. Based on the preliminary results obtained in this work, around $30 \%$ of the BFG produced in the steel mill could be decarbonised through this $\mathrm{Ca}-\mathrm{Cu}$ reactor scheme using exclusively the available COG in the calcination/reduction reactor.

A detailed analysis of this process integrated into a steel mill has been performed by Martínez et al. (2018), who considered also the balances of the steel mill processes for evaluating the impact of integrating the $\mathrm{Ca}-\mathrm{Cu}$ process on the reduction of the $\mathrm{CO}_{2}$ emissions in the steel mill. The integration of the heat available throughout the $\mathrm{Ca}-\mathrm{Cu}$ process into a steam cycle for producing electricity has been also solved in this analysis, which elucidated the large reduction in electricity consumption that may be achieved compared with the reference steel mill process with a post-combustion $\mathrm{CO}_{2}$ capture process based on amine chemical absorption. The possibility of recovering a big fraction of the energy introduced with the fuel in the calcination/reduction reactor as high temperature heat in the SEGWS unit allows producing a large amount of steam for the steam cycle, which makes the electricity import to be reduced. Moreover, the possibility of increasing the steel production capacity of the plant up to $10.5 \%$ by means of a direct reduced iron (DRI) route using the excess $\mathrm{H}_{2}$-rich gas produced in the Ca$\mathrm{Cu}$ process has been proposed. Considering the results from Martínez et al. (2018), the Ca-Cu process scheme shown in Fig. 12 has been demonstrated to be theoretically viable for fulfilling the almost complete decarbonisation of a steel mill when using additional natural gas as fuel in the calcination/reduction reactor. Around $92 \%$ of $\mathrm{CO}_{2}$ capture ratio could be reached in the whole steelworks, resulting in $1.4 \mathrm{~kg}_{\mathrm{CO} 2} /$ $t_{\text {HRC }}$ emitted in this case.

\subsection{Ammonia production with inherent low $\mathrm{CO}_{2}$ emissions through the $\mathrm{Ca}$ - $\mathrm{Cu}$ process}

The well-established ammonia production process is based on three main steps, namely (i) syngas production by steam reforming of natural gas by means of a two-step reforming process, (ii) conditioning of syngas for removing $\mathrm{CO}$ and $\mathrm{CO}_{2}$ through a two-step WGS reactor, a $\mathrm{CO}_{2}$ removal unit and a methanation step, and (iii) the ammonia synthesis loop itself. Most of the modifications and advancements made over the years to this well-established process concern the reforming step, looking for a reduction of the specific primary energy consumption per unit of ammonia produced and a plant capacity increase. However, due to the large energy demand needed for running the reforming reactions the specific primary energy consumption of the commercial process is still higher than the minimum (Appl, 2002).

Based on the improved performance of the $\mathrm{Ca}-\mathrm{Cu}$ process as part of a standalone hydrogen production plant and the inherent co-production of pure streams of $\mathrm{H}_{2}$ and $\mathrm{N}_{2}$ as part of its products, the Ca-Cu process is a promising technology to be integrated in an ammonia production process. This application has been recently studied by Martínez et al. (2017), who proposed the schematic shown in Fig. 13. The synthesis gas production and conditioning steps used in a commercial ammonia production process are replaced by the fixed-bed $\mathrm{Ca}-\mathrm{Cu}$ process shown in this figure that provides the $\mathrm{H}_{2}$ and $\mathrm{N}_{2}$ streams in the right proportion (i.e., 3:1) to be introduced into the $\mathrm{NH}_{3}$ synthesis loop. In addition to a PSA unit to purify the $\mathrm{H}_{2}$-rich gas from the SER stage, a second PSA unit is included for removing the small quantities of $\mathrm{CO}_{2}$ present in the $\mathrm{N}_{2}$-rich gas from the $\mathrm{Cu}$ oxidation stage.

Balances of a complete ammonia production plant based on the Ca$\mathrm{Cu}$ looping process were solved by Martínez et al. (2017), considering the simplified sharp fronts approach described by Fernández et al. (2012c) for calculating the Ca-Cu reactors. Operating pressure of SER, oxidation and heating stages was considered equal to 23.5 bar, whereas the S/C ratio in the SER stage was tuned for providing the heat demand in the calcination/reduction stage by exclusively the off-gas from the hydrogen PSA unit. The conventional ammonia production process has been also calculated in the mentioned work for the sake of performance comparison. Based on the calculations performed, the ammonia production process integrated with the $\mathrm{Ca}$-Cu process in Fig. 13 results in a primary energy consumption of $24 \mathrm{GJ} / \mathrm{t}_{\mathrm{NH} 3}$, which is $14 \%$ lower than 


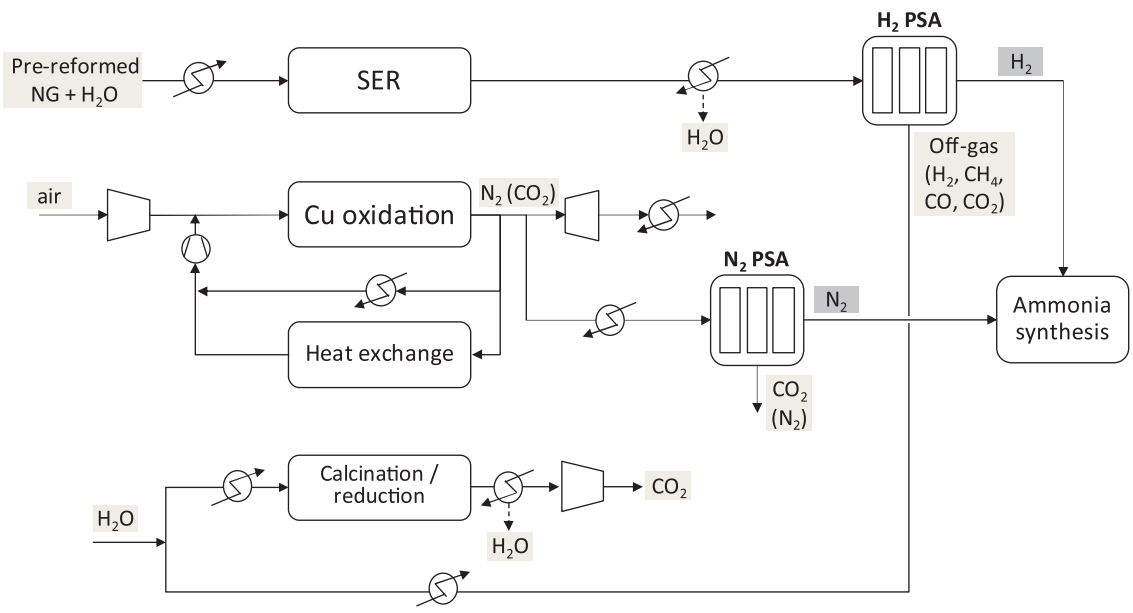

Fig. 13. Scheme of the $\mathrm{Ca}-\mathrm{Cu}$ process to be integrated with the ammonia synthesis unit (adapted from Martínez et al. (2017)).

the energy consumption of the benchmark ammonia plant. This noticeable improvement is linked to the reduction of the natural gas input needed in the $\mathrm{Ca}-\mathrm{Cu}$ based plant and the lower operating temperatures of the syngas production units (i.e. $856^{\circ} \mathrm{C}$ at SER stage outlet and $1010^{\circ} \mathrm{C}$ for the ATR outlet in the benchmark). Considering that the Ca$\mathrm{Cu}$ process needs electricity to be imported from the grid, the global specific primary energy consumption is evaluated assuming that power is generated in a state of the art natural gas combined cycle, which results in energy consumption of $26.5 \mathrm{GJ} / \mathrm{t}_{\mathrm{NH} 3}$ for the Ca-Cu based ammonia plant, vs. $27.6 \mathrm{GJ} / \mathrm{t}_{\mathrm{NH} 3}$ for the benchmark ammonia production process.

\section{Process design of Ca-Cu looping based power generation plants}

Decarbonising the power production sector can be fulfilled through two different routes: (i) directly to the flue gas released to the atmosphere of the existing plant, which contains the carbon contained in the fossil fuel used as $\mathrm{CO}_{2}$, or (ii) applying it to the fossil fuel before being burnt to generate a decarbonised fuel that is sent to the boiler or combustion chamber in the power production station. Inherent characteristics of each application lead to consider different aspects regarding the type of fuel used or the operating conditions needed in the $\mathrm{CO}_{2}$ capture process. The application of the $\mathrm{Ca}-\mathrm{Cu}$ looping process both as a post-combustion and pre-combustion $\mathrm{CO}_{2}$ capture system has been also studied for power production plants.

When applied as a post-combustion $\mathrm{CO}_{2}$ capture solution typically in coal-fired power plants, a three interconnected fluidised bed configuration operating at atmospheric pressure like the one depicted in Fig. 14 has been considered in the literature (Duhoux et al., 2016; Ozcan et al., 2015). Flue gas from the existing power plant is introduced

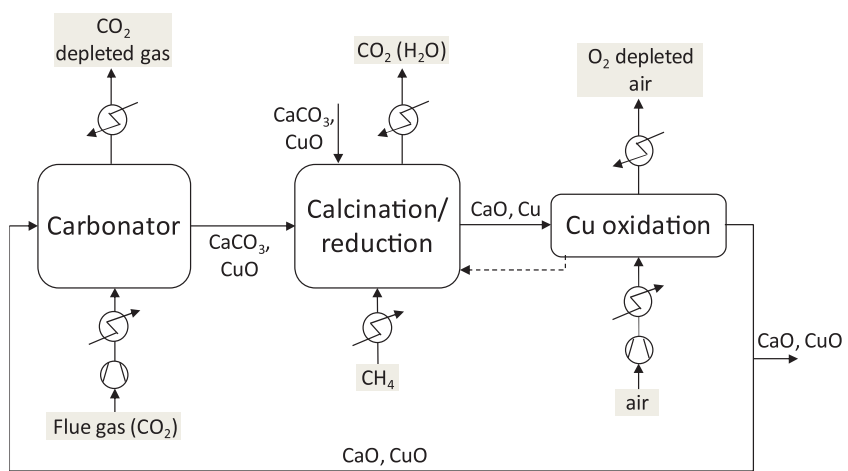

Fig. 14. Scheme of the $\mathrm{Ca}-\mathrm{Cu}$ process applied to $\mathrm{CO}_{2}$ capture from combustion flue gas (adapted from Ozcan et al. (2015)). into the carbonator reactor together with a solid stream containing $\mathrm{CaO}$ and CuO-based materials that comes from the oxidation step. In this reactor, carbonation of the $\mathrm{CaO}$ occurs at $650{ }^{\circ} \mathrm{C}$ whereas the $\mathrm{CuO}$ remains unaltered under these conditions. Solids containing $\mathrm{CaCO}_{3}$ and $\mathrm{CuO}$ are then sent to the calcination/reduction stage where natural gas is used as fuel. Once the $\mathrm{CaCO}_{3}$ has been regenerated into $\mathrm{CaO}$, the solids containing $\mathrm{CaO}$ and $\mathrm{Cu}$ are sent to the oxidation reactor. The operating temperatures chosen for the calcination/reduction and oxidation reactors are $885-900{ }^{\circ} \mathrm{C}$ and $950{ }^{\circ} \mathrm{C}$, respectively, to be able to circulate some solids from the high temperature oxidation reactor to the calcination/reduction one (indicated in dashed lines in Fig. 14) to fulfil part of the energy demand in this last reactor and so reduce $\mathrm{Cu}$-based material and fuel needs.

When solving the balances for this application, the net electric efficiency of the whole process (i.e., existing power plant $+\mathrm{Ca}-\mathrm{Cu}$ process + secondary steam cycle) ranges between 34.8-36.6\% depending on the amount of fresh sorbent make-up provided to the process (consisting in $\mathrm{CaCO}_{3}$ and CuO-based particles) (Ozcan et al., 2015). These values show that efficiency improvements can be achieved with respect to conventional post-combustion Ca-Looping process, due to the absence of the ASU. However, the large amount of natural gas needed for $\mathrm{CuO}$ reduction (between 20 and $40 \%$ of the total input according to the balances solved by Ozcan et al. (2015)) involves a significant energy penalty, as such natural gas is ultimately converted into electricity with the efficiency typical of a steam cycle, which is intrinsically much less efficient (by roughly $15-20 \%$ points) than a combined cycle that is the reference power generation technology from natural gas. Therefore, energy penalty associated to $\mathrm{CO}_{2}$ capture is shifted from electric consumption for oxygen production to inefficient conversion of high quality natural gas fuel. For the same configuration, it was estimated that separate loops between the carbonator-calcination/reduction reactors and the calcination/reduction-oxidation reactors were possible (i.e. by means of a segregation step within the calcination/reduction reactor as in the system shown in Fig. 12), solid circulation between reactors would be reduced by $10-20 \%$ while keeping the same electric efficiency (Duhoux et al., 2016). However, all these results are based on simplified process simulations and should be therefore further analysed through experimental and simulation works.

When used as a pre-combustion $\mathrm{CO}_{2}$ capture process in a natural gas combined cycle (NGCC), the Ca-Cu process is operated in a fixed bed reactors system similar to that already described for hydrogen production plants, but the $\mathrm{H}_{2}$-rich gas stream produced in the SER stage is used as fuel in the gas turbine of the combined cycle. The scheme of this Ca-Cu process application is shown in Fig. $15 . \mathrm{H}_{2}$-rich gas from the SER stage is directly converted in the gas turbine with no further treatment and additional pre-reformed natural gas is used as fuel in the 


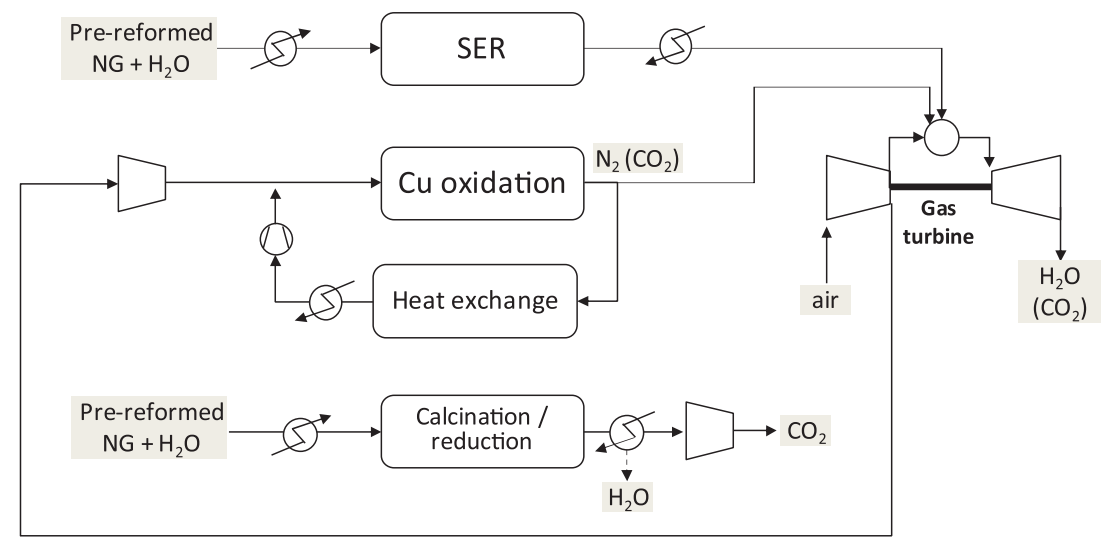

Fig. 15. Scheme of the $\mathrm{Ca}-\mathrm{Cu}$ process as a pre-combustion $\mathrm{CO}_{2}$ capture process in NGCC power plants.

calcination/reduction reactor. In this application, the $\mathrm{CO}_{2}$ capture efficiency of the whole plant is largely influenced by that of the SER stage, which is limited by the formation of a heat plateau at high temperature within the SER stage that limits the $\mathrm{CaO}$ carbonation (Martini et al., 2017). To improve the $\mathrm{CO}_{2}$ capture efficiency of the SER stage, Martini et al. (2017) evaluated different operating options (i.e., increased $\mathrm{S} / \mathrm{C}$, different initial solid bed temperatures, recirculating a fraction of the $\mathrm{H}_{2}$-rich gas, splitting SER stage into two, ...) and concluded that splitting the SER stage into two steps with intermediate gas cooling coupled with sufficiently high S/C ( $>4)$ allowed to achieve the target $\mathrm{CO}_{2}$ capture efficiency. Thanks to the two-stage SER process, part of the carbon slipped from the main SER stage is separated in this second step. Based on this advanced configuration, $\mathrm{CO}_{2}$ capture efficiency is increased up to around $90 \%$.

Based on this improved scheme, a techno-economic assessment of a NGCC based power plant based on the $\mathrm{Ca}$-Cu process has been performed, where the pressure drop of the main heat exchangers, the size of the $\mathrm{Ca}-\mathrm{Cu}$ reactors and the number of parallel reactors in the $\mathrm{Cu}$ oxidation and heat exchange stages are optimised to minimise the cost of electricity and of $\mathrm{CO}_{2}$ avoided (Martínez et al., 2019). Similarly to the results obtained in the techno-economic analysis of $\mathrm{Ca}-\mathrm{Cu}$ process hydrogen plant (Riva et al., 2018), the adoption of short reactors leads to a reduction of the reactors cost (including the functional material) and of the gas pressure drop, with beneficial effects on the electric consumption of the air compressor and of the $\mathrm{N}_{2}$ recycle fan. The optimal number of parallel reactors in the $\mathrm{Cu}$ oxidation and bed heating stages was estimated to be 5 . For the optimized Ca-Cu power plant, net electric efficiency $0.5 \%$ points higher than the benchmark power plant with pre-combustion $\mathrm{CO}_{2}$ capture by MDEA process was obtained. For the same case, an electricity cost of $82.6 € /$ MWh has been obtained, which is $2.2 € /$ MWh below the benchmark.

\section{Recommendations and outlook}

The $\mathrm{Ca}-\mathrm{Cu}$ looping process is a promising pre-combustion $\mathrm{CO}_{2}$ capture technology which allows carrying out the energy-intensive sorbent regeneration with a moderate energy penalty. Although this novel technology can be performed in different reactor configurations, the feasibility of each reaction step has been experimentally demonstrated so far only in packed-bed reactors up to TRL 4-5. Moreover, significant progress has also been made in process modelling and simulation oriented to the generation of power and its integration in industrial processes, such as $\mathrm{H}_{2}$, ammonia and steel production. However, further research is needed to facilitate the development of the $\mathrm{Ca}-\mathrm{Cu}$ process at a large scale.

Regarding the functional materials, significant advances have been made so far, but future investigations need to focus on improving their long-term mechanical stability under shifting temperatures, pressures and redox atmospheres, as a necessary step for the scale-up of the technology. Moreover, chemical performance of the materials throughout extended number of cycles (i.e. thousands of cycles) and under industrial conditions (of pressure, temperature and gas composition) should be also studied.

As for the lab-scale validation of the $\mathrm{Ca}-\mathrm{Cu}$ process, the different stages of the process should be tested under industrially relevant conditions (i.e., adiabatic reactors, particles in pellet form, SER stage at pressures above 20 bar, conditions that allow assessing the effect of the hydration issue on process performance, etc.). As with other emerging technologies, it remains important to evaluate the performance of the materials in the long term when exposed to harsh conditions after repeated cycles. It is also needed to better understand the response of the system when the chemical properties of the materials (kinetics, sorbent capacity, etc.) are partially lost, allowing for the process control design and the process model validation at larger scale.

In addition, some research gaps have been detected for the process design depending on the reactor type used. For the $\mathrm{Ca}$-Cu packed-bed systems, reducing the volume of the reactors as much as possible allows reducing the pressure drops across the reactors and the amount of functional material, turning down in this way both operational and capital costs. However, the reduction of the reactors volume may be limited by fluid-dynamic and manufacturing constrains and the resulting short cycles may cause excessive stress for the valves, increasing the importance of the auxiliary purge, rinse, pressurization and depressurization stages, often neglected in process analysis reported so far. When focused on power production, process performance studies have always been designed to achieve the highest electric efficiency under full load operation, resulting in highly thermally integrated process configurations. However, the flexibility of the system and the effect of part-load operation on the performance of the $\mathrm{Ca}-\mathrm{Cu}$ based power plant, whose importance is dramatically rising in the electric market, needs to be assessed and may make simpler and more flexible process configurations preferable over the highest efficiency process. For $\mathrm{Ca}$-Cu fluidized bed systems, future challenges rely on the design and operation of reactor arrangements based on three interconnected fluidized beds, as well as on the deeper study on an efficient segregation step to separate the $\mathrm{CaO}$ - and Cu-based particles. Also, the technical feasibility of using alternative fuels (different from natural gas) as reducing agents in the calcination/reduction operation (for example, coal or biomass) might be evaluated in order to reduce operating cost, energy penalty and/or $\mathrm{CO}_{2}$ emissions. Finally, economic analyses are needed to confirm the results recently published on power and hydrogen plants and to provide the first evaluation of the economic indicators for the $\mathrm{Ca}-\mathrm{Cu}$ process integrated in ammonia plants and steel mills.

From the state of the art review carried out in this work, and from the limitations noted in previous paragraphs, it can be concluded that 
the Ca-Cu process has inherent limitations to drastically reduce cost and energy penalties in power plant applications, while it remains an important contender for future industrial systems requiring decarbonized hydrogen from carbon-based fuel gas streams.

\section{Acknowledgements}

This work has been carried out as part of the European Commission 7th Framework Programme project ASCENT (Grant agreement No. 608512)

\section{References}

Abanades, J.C., Anthony, E.J., Wang, J., Oakey, J.E., 2005. Fluidized bed combustion systems integrating $\mathrm{CO}_{2}$ capture with CaO. Environ. Sci. Technol. 39, 2861-2866. https://doi.org/10.1021/es0496221.

Abanades, J.C., Murillo, R., 2009. Method of capturing $\mathrm{CO}_{2}$ by means of $\mathrm{CaO}$ and the exothermic reduction of a solid. US8506915 B2.

Alarcón, J.M., Fernández, J.R., 2015. $\mathrm{CaCO}_{3}$ calcination by the simultaneous reduction of $\mathrm{CuO}$ in a $\mathrm{Ca} / \mathrm{Cu}$ chemical looping process. Chem. Eng. Sci. 137, 254-267. https://doi. org/10.1016/j.ces.2015.06.030.

Alarcón, J.M., Fernández, J.R., Abanades, J.C., 2017. Study of a Cu-CuO chemical loop for the calcination of $\mathrm{CaCO}_{3}$ in a fixed bed reactor. Chem. Eng. J. 325, 208-220. https:// doi.org/10.1016/j.cej.2017.05.070.

Appl, M., 2002. Ammonia, 3. Production plants. Ullmann's Encyclopedia of Industrial Chemistry. Wiley, pp. 227-262. https://doi.org/10.1002/14356007.

ASCENT project, http://ascentproject.eu, 2019, accessed June 2018.

Baker, E.H., 1962. The CaO- $\mathrm{CO}_{2}$ system in the pressure range 1-300 atm. J. Chem. Soc $70,464-470$.

Balasubramanian, B., Ortiz, A.L., Kaytakoglu, S., Harrison, D.P., 1999. Hydrogen from methane in a single-step process. Chem. Eng. Sci. 54, 3543-3552. https://doi.org/10. 1016/S0009-2509(98)00425-4.

Boot-Handford, M.E., Abanades, J.C., Anthony, E.J., Blunt, M.J., Brandani, S., Mac Dowell, N., Fernández, J.R., Ferrari, M.C., Gross, R., Hallett, J.P., Haszeldine, R.S., Heptonstall, P., Lyngfelt, A., Makuch, Z., Mangano, E., Porter, R.T.J., Pourkashanian, M., Rochelle, G.T., Shah, N., Yao, J.G., Fennell, P.S., 2014. Carbon capture and storage update. Energy Environ. Sci. 7, 130-189. https://doi.org/10.1039/ C3EE42350F.

Borghei, M., Karimzadeh, R., Rashidi, A., Izadi, N., 2010. Kinetics of methane decomposition to $\mathrm{COx}$-free hydrogen and carbon nanofiber over $\mathrm{Ni}-\mathrm{Cu} / \mathrm{MgO}$ catalyst. Int. J. Hydrogen Energy 35, 9479-9488. https://doi.org/10.1016/J.IJHYDENE.2010.05. 072 .

Di Giuliano, A., Gallucci, K., 2018. Sorption enhanced steam methane reforming based on nickel and calcium looping: a review. Chem. Eng. Process. Process Intensif. 130 240-252. https://doi.org/10.1016/J.CEP.2018.06.021.

Díez-Martín, L., Grasa, G., Murillo, R., Martini, M., Gallucci, F., van Sint Annaland, M., 2018a. Determination of the oxidation kinetics of high loaded CuO-based materials under suitable conditions for the $\mathrm{Ca} / \mathrm{Cu} \mathrm{H}_{2}$ production process. Fuel 219, 76-87. https://doi.org/10.1016/J.FUEL.2018.01.064.

Díez-Martín, L., López, J.M., Fernández, J.R., Martínez, I., Grasa, G., Murillo, R., 2018b. Complete $\mathrm{Ca} / \mathrm{Cu}$ cycle for $\mathrm{H}_{2}$ production via $\mathrm{CH}_{4}$ sorption enhanced reforming in a lab-scale fixed bed reactor. Chem. Eng. J. 350, 1010-1021. https://doi.org/10.1016/ j.cej.2018.06.049.

Díez-Martín, L., Martínez, I., Grasa, G., Murillo, R., 2018c. Investigation of the reduction kinetics of high loaded CuO-based materials suitable for the $\mathrm{Ca} / \mathrm{Cu}$ looping process. Fuel 230, 376-389. https://doi.org/10.1016/J.FUEL.2018.05.054.

Duhoux, B., Mehrani, P., Lu, D.Y., Symonds, R.T., Anthony, E.J., Macchi, A., 2016. Combined calcium looping and chemical looping combustion for post combustion carbon dioxide capture: process simulation and sesitivity analysis. Energy Technol. 4, 1158-1170. https://doi.org/10.1002/ente.201600024.

Edenhofer, O., Pichs-Madruga, R., Sokona, Y., Farahani, E., Kadner, S., Seyboth, K., Adler, A., Baum, I., Brunner, S., Eickemeier, P., Kriemann, B., Savolaninen, J., 2014. IPCC, 2014: climate change 2014: mitigation of climate change. Contribution of Working Group III to the Fifth Assessment Report of the Intergovernmental Panel on Climate Change. Cambridge University Press, Cambridge, United Kingdom and New York, NY, USA.

Edwards, M.F., Richardson, J.F., 1968. Gas dispersion in packed beds. Chem. Eng. Sci. 23, 109-123. https://doi.org/10.1016/0009-2509(68)87056-3.

Eigenberger, G., 2012. Fixed-Bed reactors. Ullmann's Encycl. Ind. Chem. https://doi.org/ 10.1002/14356007.b04.

Erans, M., Manovic, V., Anthony, E.J., 2016. Calcium looping sorbents for $\mathrm{CO}_{2}$ capture. Appl. Energy 180, 722-742. https://doi.org/10.1016/J.APENERGY.2016.07.074.

Fang, F., Li, Z.S., Cai, N.S., 2009. Experiment and modeling of $\mathrm{CO}_{2}$ capture from flue gases at high temperature in a fluidized bed reactor with Ca-Based sorbents. Energy Fuels 23, 207-216. https://doi.org/10.1021/ef800474n.

Fernández, J.R., Abanades, J.C., 2016. $\mathrm{CO}_{2}$ capture from the calcination of $\mathrm{CaCO}_{3}$ using iron oxide as heat carrier. J. Clean. Prod. 112, 1211-1217. https://doi.org/10.1016/ j.jclepro.2015.06.010

Fernández, J.R., Abanades, J.C., 2017a. Overview of the Ca-Cu looping process for hydrogen production and/or power generation. Curr. Opin. Chem. Eng. https://doi.org/ 10.1016/j.coche.2017.04.010.

Fernández, J.R., Abanades, J.C., 2017b. Reactor design for sorption-enhanced reforming using CaCu chemical loops. Adv. Chem. Eng. 51, 207-260. https://doi.org/10.1016/ bs. ache. 2017.07.003.

Fernández, J.R., Abanades, J.C., 2017c. Optimized design and operation strategy of a Ca$\mathrm{Cu}$ chemical looping process for hydrogen production. Chem. Eng. Sci. 166, 144-160. https://doi.org/10.1016/j.ces.2017.03.039.

Fernández, J.R., Abanades, J.C., 2019. Experimental testing and model validation of the calcination of calcium carbonate by the reduction of copper oxide with $\mathrm{CH}_{4}$. Chem. Eng. Sci. 193, 120-132. https://doi.org/10.1016/J.CES.2018.09.001.

Fernández, J.R., Abanades, J.C., Grasa, G., 2012a. Modeling of sorption enhanced steam methane reforming - part II: simulation within a novel $\mathrm{Ca} / \mathrm{Cu}$ chemical loop process for hydrogen production. Chem. Eng. Sci. 84, 12-20. https://doi.org/10.1016/j.ces. 2012.07.050.

Fernández, J.R., Abanades, J.C., Murillo, R., 2012b. Modeling of sorption enhanced steam methane reforming in an adiabatic fixed bed reactor. Chem. Eng. Sci. 84, 1-11. https://doi.org/10.1016/j.ces.2012.07.039.

Fernández, J.R., Abanades, J.C., Murillo, R., Grasa, G., 2012c. Conceptual design of a hydrogen production process from natural gas with $\mathrm{CO}_{2}$ capture using a $\mathrm{Ca}-\mathrm{Cu}$ chemical loop. Int. J. Greenh. Gas Control 6, 126-141. https://doi.org/10.1016/j. ijggc.2011.11.014.

Fernández, J.R., Abanades, J.C., Murillo, R., 2013. Modeling of Cu oxidation in adiabatic fixed-bed reactor with $\mathrm{N}_{2}$ recycling in a Ca/Cu chemical loop. Chem. Eng. J. 232, 442-452. https://doi.org/10.1016/J.CEJ.2013.07.115.

Fernández, J.R., Abanades, J.C., Murillo, R., 2014. Modeling of $\mathrm{Cu}$ oxidation in an adiabatic fixed-bed reactor with $\mathrm{N}_{2}$ recycling. Appl. Energy 113, 1945-1951. https:// doi.org/10.1016/j.apenergy.2013.02.013.

Fernández, J.R., Alarcón, J.M., Abanades, J.C., 2016. Investigation of a fixed-bed reactor for the calcination of $\mathrm{CaCO} 3$ by the simultaneous reduction of $\mathrm{CuO}$ with a fuel gas. Ind. Eng. Chem. Res. 55, 5128-5132. https://doi.org/10.1021/acs.iecr.5b04073.

Fernández, J.R., Martínez, I., Abanades, J.C., Romano, M.C., 2017. Conceptual design of a $\mathrm{Ca}-\mathrm{Cu}$ chemical looping process for hydrogen production in integrated steelworks. Int. J. Hydrogen Energy 42, 11023-11037. https://doi.org/10.1016/j.ijhydene.2017. 02.141.

Fernández, J.R., Alarcón, J.M., Abanades, J.C., 2018. Study of the calcination of $\mathrm{CaCO}_{3}$ by means of a $\mathrm{Cu} / \mathrm{CuO}$ chemical loop using methane as fuel gas. Catal. Today In press. https://doi.org/10.1016/J.CATTOD.2018.02.053.

García-Labiano, F., de Diego, L.F., Adánez, J., Abad, A., Gayán, P., 2004. Reduction and oxidation kinetics of a copper-based oxygen carrier prepared by impregnation for chemical-looping combustion. Ind. Eng. Chem. Res. 43, 8168-8177. https://doi.org/ 10.1021/ie0493311.

García-Lario, A.L., Martínez, I., Murillo, R., Grasa, G., Fernández, J.R., Abanades, J.C., 2013. Reduction kinetics of a high load $\mathrm{Cu}$-based pellet suitable for $\mathrm{Ca} / \mathrm{Cu}$ chemical loops. Ind. Eng. Chem. Res. 52, 1481-1490. https://doi.org/10.1021/ie3012598.

Grasa, G., Navarro, M.V., López, J.M., Díez-Martín, L., Fernández, J.R., Murillo, R., 2017. Validation of the $\mathrm{H}_{2}$ production stage via SER under relevant conditions for the $\mathrm{Ca}$ / $\mathrm{Cu}$ reforming process practical application. Chem. Eng. J. 324, 266-278. https://doi. org/10.1016/j.cej.2017.04.134.

Gunn, D.J., 1978. Transfer of heat or mass to particles in fixed and fluidised beds. Int. J. Heat Mass Transf. 21, 467-476. https://doi.org/10.1016/0017-9310(78)90080-7.

Gunn, D.J., Misbah, M.M.A., 1993. Bayesian estimation of heat transport parameters in fixed beds. Int. J. Heat Mass Transf. 36, 2209-2221. https://doi.org/10.1016/S00179310(05)80152-8.

Hamers, H.P., Gallucci, F., Cobden, P.D., Kimball, E., van Sint Annaland, M., 2014. CLC in packed beds using syngas and $\mathrm{CuO} / \mathrm{Al}_{2} \mathrm{O}_{3}$ : model description and experimental validation. Appl. Energy 119, 163-172. https://doi.org/10.1016/J.APENERGY.2013. 12.053.

Harrison, D.P., 2008. Sorption-enhanced hydrogen production: a review. Ind. Eng. Chem. Res. 47, 6486-6501. https://doi.org/10.1021/ie800298z.

Hodgson, P., Sceats, M., Vincent, A., Hills, T., 2018. Direct separation calcination technology for carbon capture: demonstrating a low cost solution for the lime and cement industries in the LEILAC project. 14th Conference on Greenhouse Gas Control Technologies.

Jansen, D., Gazzani, M., Manzolini, G., Van Dijk, E., Carbo, M., 2015. Pre-combustion CO capture. Int. J. Greenh. Gas Control 40, 167-187. https://doi.org/10.1016/j.ijggc. 2015.05.028.

Johnsen, K., Ryu, H.J., Grace, J.R., Lim, C.J., 2006. Sorption-enhanced steam reforming of methane in a fluidized bed reactor with dolomite as $\mathrm{CO}_{2}$-acceptor. Chem. Eng. Sci. 61, 1195-1202. https://doi.org/10.1016/j.ces.2005.08.022.

Kierzkowska, A.M., Pacciani, R., Müller, C.R., 2013. CaO-based $\mathrm{CO}_{2}$ sorbents: from fundamentals to the development of new, highly effective materials. ChemSusChem 6, 1130-1148. https://doi.org/10.1002/cssc.201300178.

Lee, D.K., 2004. An apparent kinetic model for the carbonation of calcium oxide by carbon dioxide. Chem. Eng. J. 100, 71-77. https://doi.org/10.1016/j.cej.2003.12. 003.

Lopez Ortiz, A., Harrison, D.P., 2001. Hydrogen production using sorption-enhanced reaction. Ind. Eng. Chem. Res. 40, 5102-5109. https://doi.org/10.1021/ie001009c.

Martínez, I., Murillo, R., Grasa, G., Rodríguez, N., Abanades, J.C., 2011. Conceptual design of a three fluidised beds combustion system capturing $\mathrm{CO}_{2}$ with $\mathrm{CaO}$. Int. J. Greenh. Gas Control 5, 498-504. https://doi.org/10.1016/j.ijggc.2010.04.017.

Martínez, I., Grasa, G., Murillo, R., Arias, B., Abanades, J.C., 2012. Kinetics of calcination of partially carbonated particles in a Ca-looping system for $\mathrm{CO}_{2}$ capture. Energy Fuels 26. https://doi.org/10.1021/ef201525k.

Martínez, I., Murillo, R., Grasa, G., Fernández, J.R., Abanades, J.C., 2013a. Integrated combined cycle from natural gas with $\mathrm{CO}_{2}$ capture using a Ca-Cu chemical loop. AIChE J. 59, 2780-2794. https://doi.org/10.1002/aic.14054.

Martínez, I., Romano, M.C., Chiesa, P., Grasa, G., Murillo, R., 2013b. Hydrogen production through sorption enhanced steam reforming of natural gas: thermodynamic plant 
assessment. Int. J. Hydrogen Energy 38, 15180-15199. https://doi.org/10.1016/j. ijhydene.2013.09.062.

Martínez, I., Romano, M.C., Fernández, J.R., Chiesa, P., Murillo, R., Abanades, J.C., 2014. Process design of a hydrogen production plant from natural gas with $\mathrm{CO}_{2}$ capture based on a novel $\mathrm{Ca} / \mathrm{Cu}$ chemical loop. Appl. Energy 114, 192-208. https://doi.org/ 10.1016/j.apenergy.2013.09.026.

Martínez, I., Grasa, G., Parkkinen, J., Tynjälä, T., Hyppänen, T., Murillo, R., Romano, M.C., 2016. Review and research needs of Ca-Looping systems modelling for postcombustion $\mathrm{CO}_{2}$ capture applications. Int. J. Greenh. Gas Control 50, 271-304. https://doi.org/10.1016/j.ijggc.2016.04.002.

Martínez, I., Armaroli, D., Gazzani, M., Romano, M.C., 2017. Integration of the Ca-Cu process in Ammonia production plants. Ind. Eng. Chem. Res. 56, 2526-2539. https:// doi.org/10.1021/acs.iecr.6b04615.

Martínez, I., Fernández, J.R., Abanades, J.C., Romano, M.C., 2018. Integration of a fluidised bed Ca-Cu chemical looping process in a steel mill. Energy 163, 570-584. https://doi.org/10.1016/J.ENERGY.2018.08.123.

Martínez, I., Martini, M., Riva, L., Gallucci, F., Van Sint Annaland, M., Romano, M.C., 2019. Techno-economic analysis of a natural gas combined cycle integrated with a $\mathrm{Ca}-\mathrm{Cu}$ looping process for low $\mathrm{CO}_{2}$ emission power production. Int. J. Greenh. Gas Control 81, 216-239. https://doi.org/10.1016/j.ijggc.2018.12.026.

Martini, M., van den Berg, A., Gallucci, F., van Sint Annaland, M., 2016. Investigation of the process operability windows for $\mathrm{Ca}$-Cu looping for hydrogen production with $\mathrm{CO}_{2}$ capture. Chem. Eng. J. 303, 73-88. https://doi.org/10.1016/j.cej.2016.05.135.

Martini, M., Martínez, I., Romano, M.C., Chiesa, P., Gallucci, F., van Sint Annaland, M., 2017. Increasing the carbon capture efficiency of the $\mathrm{Ca} / \mathrm{Cu}$ looping process for power production with advanced process schemes. Chem. Eng. J. 328, 304-319. https://doi.org/10.1016/j.cej.2017.07.048.

Navarro, M.V., López, J.M., García, T., Grasa, G., Murillo, R., 2017. Catalyst evaluation for high-purity $\mathrm{H}_{2}$ production by sorption-enhanced steam-methane reforming coupled to a Ca/Cu process. J. Power Sources 363, 117-125. https://doi.org/10.1016/J. JPOWSOUR.2017.07.075.

Noorman, S., van Sint Annaland, M., Kuipers, H., 2007. Packed bed reactor technology for chemical-looping combustion. Ind. Eng. Chem. Res. 46, 4212-4220. https://doi.org/ 10.1021/ie061178i.

Noorman, S., van Sint Annaland, M., Kuipers, J.A.M., 2010. Experimental validation of packed bed chemical-looping combustion. Chem. Eng. Sci. 65, 92-97. https://doi. org /10.1016/J.CES.2009.02.004.

Numaguchi, T., Kikuchi, K., 1988. Intrinsic kinetics and design simulation in a complex reaction network: steam-methane reforming. Chem. Eng. Sci. 43, 2295-2301. https://doi.org/10.1016/0009-2509(88)87118-5.

Ochoa-Fernandez, E., Haugen, G., Zhao, T., Ronning, M., Aartun, I., Borresen, B., Rytter, E., Ronnekleiv, M., Chen, D., 2007. Process design simulation of $\mathrm{H}_{2}$ production by sorption enhanced steam methane reforming: evaluation of potential $\mathrm{CO}_{2}$ acceptors. Green Chem. 9, 654-662. https://doi.org/10.1039/b614270b.

Ozcan, D.C., Macchi, A., Lu, D.Y., Kierzkowska, A.M., Ahn, H., Müller, C.R., Brandani, S., 2015. Ca-Cu looping process for $\mathrm{CO}_{2}$ capture from a power plant and its comparison with Ca-looping, oxy-combustion and amine-based $\mathrm{CO}_{2}$ capture processes. Int. J. Greenh. Gas Control 43, 198-212. https://doi.org/10.1016/J.IJGGC.2015.10.021.

Perreault, P., Patience, G.S., 2016. Carbonation and deactivation kinetics of a mixed calcium oxide-copper oxide sorbent/oxygen carrier for post-combustion carbon dioxide capture. Chem. Eng. J. 306, 726-733. https://doi.org/10.1016/J.CEJ.2016.07. 114.

Qin, C., Feng, B., Yin, J., Ran, J., Zhang, L., Manovic, V., 2015. Matching of kinetics of $\mathrm{CaCO}_{3}$ decomposition and $\mathrm{CuO}$ reduction with $\mathrm{CH}_{4}$ in $\mathrm{Ca}-\mathrm{Cu}$ chemical looping. Chem. Eng. J. 262, 665-675. https://doi.org/10.1016/J.CEJ.2014.10.030.
Qin, C., Manovic, V., Ran, J., Feng, B., 2016a. Simulation of the calcination of a core-inshell $\mathrm{CuO} / \mathrm{CaCO}_{3}$ particle for $\mathrm{Ca}-\mathrm{Cu}$ chemical looping. Fuel 181, 522-530. https:// doi.org/10.1016/J.FUEL.2016.05.035.

Qin, C., Yin, J., Feng, B., Ran, J., Zhang, L., Manovic, V., 2016b. Modelling of the calcination behaviour of a uniformly-distributed $\mathrm{CuO} / \mathrm{CaCO}_{3}$ particle in $\mathrm{Ca}-\mathrm{Cu}$ chemical looping. Appl. Energy 164, 400-410. https://doi.org/10.1016/J.APENERGY.2015. 11.059 .

Reitz, M., Junk, M., Ströhle, J., Epple, B., 2015. $\mathrm{CO}_{2}$ capture in a 300 kWth indirectly heated fluidized bed pilot plant: operating experience and results. 6th High Temperature Solid Looping Cycles Network Meeting 1-2.

Riva, L., Martínez, I., Martini, M., Gallucci, F., van Sint Annaland, M., Romano, M.C., 2018. Techno-economic analysis of the $\mathrm{Ca}$-Cu process integrated in hydrogen plants with $\mathrm{CO}_{2}$ capture. Int. J. Hydrogen Energy 43, 15720-15738. https://doi.org/10. 1016/J.IJHYDENE.2018.07.002.

Rodríguez, N., Alonso, M., Abanades, J.C., 2011. Experimental investigation of a circulating fluidized-bed reactor to capture $\mathrm{CO}_{2}$ with $\mathrm{CaO}$. AIChE J. 57, 1356-1366. https://doi.org/10.1002/aic.12337.

Romano, M.C., Cassotti, E.N., Chiesa, P., Meyer, J., Mastin, J., 2011. Application of the sorption enhanced-steam reforming process in combined cycle-based power plants. Energy Procedia 1125-1132. https://doi.org/10.1016/j.egypro.2011.01.164.

Romano, M.C., Anantharaman, R., Arasto, A., Ozcan, D.C., Ahn, H., Dijkstra, J.W., Carbo, M., Boavida, D., 2013. Application of advanced technologies for $\mathrm{CO}_{2}$ capture from industrial sources. Energy Procedia 7176-7185. https://doi.org/10.1016/j.egypro. 2013.06.655.

San Pio, M.A., Martini, M., Gallucci, F., Roghair, I., van Sint Annaland, M., 2018. Kinetics of $\mathrm{CuO} / \mathrm{SiO}_{2}$ and $\mathrm{CuO} / \mathrm{Al}_{2} \mathrm{O}_{3}$ oxygen carriers for chemical looping combustion. Chem. Eng. Sci. 175, 56-71. https://doi.org/10.1016/J.CES.2017.09.044.

Santos, S., 2013. Iron and Steel CCS Study (Techno-economics Integrated Steel Mill). IEA Publications.

Shimizu, T., Hirama, T., Hosoda, H., Kitano, K., Inagaki, M., Tejima, K., 1999. A twin fluid-bed reactor for removal of $\mathrm{CO}_{2}$ from combustion processes. Trans. IchemE 77, 62-68.

Snoeck, J.W., Froment, G.F., Fowles, M., 2002. Steam/ $\mathrm{CO}_{2}$ reforming of methane. Carbon filament formation by the boudouard reaction and gasification by $\mathrm{CO}_{2}$, by $\mathrm{H}_{2}$, and by steam: kinetic study. Ind. Eng. Chem. Res. 41, 4252-4265. https://doi.org/10.1021/ ie010666h.

Spallina, V., Marinello, B., Gallucci, F., Romano, M.C., Van Sint Annaland, M., 2017. Chemical looping reforming in packed-bed reactors: modelling, experimental validation and large-scale reactor design. Fuel Process. Technol. 156, 156-170. https:// doi.org/10.1016/j.fuproc.2016.10.014.

Voldsund, M., Jordal, K., Anantharaman, R., 2016. Hydrogen production with $\mathrm{CO}_{2}$ capture. Int. J. Hydrogen Energy 41, 4969-4992. https://doi.org/10.1016/j.ijhydene. 2016.01.009.

Vortmeyer, D., Berninger, R., 2018. Comments on the paper, theoretical prediction of effective heat transfer parameters in packed beds by Anthony Dixon and D. L. Cresswell [AIChE J., 25, 663 (1979)]. AIChE J. 28, 508-510. https://doi.org/10. 1002/aic.690280321.

Xu, J., Froment, G.F., 1989. Methane steam reforming, methanation and water-gas shift .1. Intrinsic kinetics. AIChE J. 35, 88-96. https://doi.org/10.1002/aic.690350109.

Yi, K.B., Harrison, D.P., 2005. Low-pressure sorption-enhanced hydrogen production. Ind Eng. Chem. Res. 44, 1665-1669. https://doi.org/10.1021/ie048883g.

Zhou, Z., Han, L., Bollas, G.M., 2013. Model-based analysis of bench-scale fixed-bed units for chemical-looping combustion. Chem. Eng. J. 233, 331-348. https://doi.org/10. 1016/J.CEJ.2013.08.025 